Jerzy Menkes

\title{
Immunitet jurysdykcyjny organizacji międzynarodowej - immunitet jurysdykcyjny państwa: kierunki wektorów
}

\section{Obszar badania}

Immunitety jurysdykcyjne podmiotów prawa międzynarodowego są instytucjami wytworzonymi w rezultacie wielokrotnego rozszczepienia immunitetu suwerena-państwa na instytucje ${ }^{1}$, z których część obejmowała relacje wewnętrzne, część zaś objęła wymiar zewnętrzny funkcjonowania tego podmiotu (państwa) - stosunki międzynarodowe ${ }^{2}$. W praktyce norma prawa krajowego - immunitet

${ }^{1}$ Wskazują na to zgodnie autorzy licznych opracowań m.in. Böhre, von Dewall, Middel, Steer, szeroko uzasadniając w badaniu pogląd ,The history of international immunity is grounded in diplomatic immunity, a concept which has evolved over centuries from the need for Nation States to dialogue and to secure the unhindered fulfilment of diplomatic functions, such as immunity from criminal and civil litigation and a guarantee of safe passage. International immunity is classically divided into three categories; sovereign immunity held by States, diplomatic immunity afforded to individuals as representatives of States, and organisational immunities granted to international organisations. The essence of the immunities afforded to representatives of foreign territories has always been to secure the unhindered fulfilment of diplomatic functions, such as immunity from criminal and civil litigation and a guarantee of safe passage". V. A. Böhre, S. E. von Dewall, I. J. Middel, C. E. Steer, The (Non-)Application of International Law by the ILO Administrative Tribunal: possible legal avenues for establishing responsibility, July 2004, s. 11-15, http://www.iowatch. org/ legal/amsterdam.pdf. Patrz również: N. Hanrahan, A History of Diplomatic Immunity and the Development of International Organizations, http://www.caio-ch.org/reforms/Intern_Paper_I.pdf.

${ }^{2}$ U źródeł stała zróżnicowana praktyka, m.in. spór poprzedzający Act Preserving the Privileges of Ambasadors brytyjskiej Królowej Anny z 1708 r. (wytworzony Ustawą stan prawny stał się wzorcem międzynarodowym - został powtórzony m.in. w amerykańskiej regulacji z 1790 r.), 
jurysdykcyjny suwerena-państwa (znany krajowym porządkom prawnym) - objęła swoim zakresem podmioty w stosunku do tego suwerena zewnętrzne i niepodlegające jego władzy, ale uznane za równe wobec prawa $^{3}$, co nastąpiło wraz z pojawieniem się suwerena $\mathrm{w}$ obrocie międzynarodowym ${ }^{4}$ i w konsekwencji

a wywołany aresztowaniem ambasadora Cara Piotra Wielkiego Matwiejewa (szerzej J. i J. Baliccy, Jak to $w$ dyplomacji ładnie, Warszawa 1980, s. 177-179); również patrz: hasło „extraterritoriality”, http://www.britannica.com/EBchecked/topic/ 199129/extraterritoriality

Car Rosji, sprzeciwiając się zamachowi na ambasadora, mógł odwołać się do praktyki datowanej od czasów starożytnych odnotowanego przez Herodota oczekiwania ze strony króla perskiego Dariusza respektowania przez Greków statusu Heroldów, wojen (drugiej punickiej i Kandalur), dla przebiegu których status posłów miał istotne znaczenie, i opinii prawnej papieża Gelazjusza I; szerzej F. Przetacznik, Nietykalność osobista przedstawicieli dyplomatycznych, Warszawa 1970, s. 13-38, również S. E. Nahlik, Narodziny nowożytnej dyplomacji, Wrocław-Warszawa-KrakówGdańsk 1971, s. 164 i nast.

${ }^{3}$ Patrz: uzasadnienie koncepcji immunitetu absolutnego Sędziego Sądu Najwyższego USA Marshalla; stwierdził on (w orzeczeniu w sprawie The Schoonere Exchange v. McFadden (11 U. S. 116 (1812)), że immunitet jurysdykcyjny państwa - to, że sądy USA nie będą obrażać godności innego narodu/państwa poprzez przypisywanie sobie jurysdykcji w stosunku do niego jest wynikiem stanu pełnego i całkowitego władztwa państwa na własnym (!) terytorium i faktu, że władza sądownicza jest jednym z elementów suwerenności posiadanej przez naród „This full and absolute territorial jurisdiction, being alike the attribute of every sovereign and being incapable of conferring extraterritorial power, would not seem to contemplate foreign sovereigns nor their sovereign rights as its objects. One sovereign being in no respect amenable to another, and being bound by obligations of the highest character not to degrade the dignity of his nation by placing himself or its sovereign rights within the jurisdiction of another, can be supposed to enter a foreign territory only under an express license, or in the confidence that the immunities belonging to his independent sovereign station, though not expressly stipulated, are reserved by implication, and will be extended to him.

This perfect equality and absolute independence of sovereigns, and this common interest impelling them to mutual intercourse, and an interchange of good offices with each other, have given rise to a class of cases in which every sovereign is understood to waive the exercise of a part of that complete exclusive territorial jurisdiction which has been stated to be the attribute of every nation", http://supreme.justia.com/ us/11/116/case.html. Na uwagę zasługuje fakt, że przedmiotowy dla sprawy The Schoonere Exchange v. McFadden status prawny statków państwowych został uregulowany w sposób różny (zrównano status wszystkich statków) od wyznaczonego orzeczeniem w Konwencji brukselskiej z 1926 r.; patrz: H. J. Steiner, D. F. Vagts, H. Hongju Koh, Transnational Legal Problems. Materials and Texts, New York 1994, s. 757-762, szerzej również J. Sutor, Przywileje i immunitety międzynarodowe, Warszawa 1973, s. 29-34.

${ }^{4}$ Patrz szerzej: Second report on jurisdictional immunities of States and their property, autorstwa Sompong Sucharitkul, Special Rapporteur (s. 214 i 215) „The principle of international law regarding State immunity has developed principally from the judicial practice of States. Municipal courts have been primarily responsible for the growth and progressive development of a body of customary rules governing the relations of nations in this particular connection. The opinions of writers and international conventions relating to State immunity are practically all of subsequent growth, although there is markedly a growing interest appreciable in the writings of contemporary publicists and in relatively recent provisions of treaties and international conventions, as well as national legislation. The scantiness of pre-nineteenth century judicial decisions bearing upon the question of jurisdictional immunities of States serves as eloquent explanation for the total absence of reference to the topic in the classics of international law and the complete silence in earlier treaties and internal laws", http://untreaty.un.org/ilc/publications/yearbooks/Ybkvolumes(e)/ILC_1980_v2_p1_e.pdf. 
stała się (również) normą prawa międzynarodowego 5 . Dla uzasadnienia immunitetów przywoływano koncepcje eksterytorialności personalnej lub funkcjonalnej. Oczywiście w pewnym uproszeniu można twierdzić - i to w porządku westfalskim decyduje wyłącznie - że immunitet jurysdykcyjny w międzynarodowym obrocie prawnym występuje w sprzężeniu zwrotnym $\mathrm{z}$ suwerennością i równością państwa. Istotą suwerenności-bycia suwerenem jest niebycie podporządkowanym władzy jakiegokolwiek innego podmiotu (co oczywiście nie jest tożsame $\mathrm{z}$ brakiem podporządkowania prawu), sprawowanie jurysdykcji jest zaś zawsze wykonywaniem władzy - zwierzchnictwa. Immunitetem ${ }^{6}$ jurysdykcyjnym w szerokim rozumieniu jest więc niepodleganie obcej jurysdyk$\mathrm{cji}^{7}$ (,exemption from the application or jurisdiction of local law or tribunals", „The immunity of a foreign sovereign, its agents, and its instrumentalities from litigation in U.S. courts"”) - jurysdykcji władz innego podmiotu ${ }^{10}$; tę regułę zamknąć można w klasycznej paremii par in parem non habet imperium ${ }^{11}$.

${ }_{5}^{5}$ Jak się zgodnie uznaje termin do słownika prawa międzynarodowego wprowadził pod koniec XVIII w. G. F. von Martens, za ojca koncepcji - rozwiniętej przez H. Grocjusza i S. von Pufendorfa - uznawany jest P. Ayraut.; patrz: definicja Extraterritoriality, Encyclopedia Britannica, 2008. Encyclopedia Britannica Online.

${ }^{6}$ Hasło „immunity” jest definiowane ogólnie jako „Any exemption from a duty, liability, or service of process"; Black's Law Dictionary, St. Paul 1999.

7 Tak np. KPM ,'Immunity' is a legal concept which can be expressed in terms of jural relationship. Just as a 'right' is correlated to a corresponding 'duty' incumbent on another party, 'immunity' to which a person or party or State is entitled is correlated to 'no power' on the part of the corresponding authority. It signifies absence or lack of power, or necessity to withhold or suspend the exercise of such power. In other words, the expression 'immunity' connotes the non-existence of power or non-amenability to the jurisdiction of the national authorities of a territorial State", tamże, s. 204.

${ }^{8}$ Merriam-Webster's Dictionary of Law, Springfield, Massachusetts, 1996.

${ }^{9}$ Hasło „foreign immunity”, Black's...

${ }_{10} \mathrm{Z}$ tego rozumienia jurysdykcji władz innego podmiotu wyłączona (co najmniej od powołania i uznania jurysdykcji STSM) jest jurysdykcja sprawowana przez trybunały i sądy międzynarodowe, w tym przede wszystkim MTS i inne wyspecjalizowane organy sądownicze. Są to jednak przypadki, w których sąd lub trybunał międzynarodowy rozstrzyga spór/spory pomiędzy państwami (lub w niektórych przypadkach: WTO spór/spory pomiędzy podmiotami prawa międzynarodowego. Wyłączona jest również jurysdykcja - w stosunku do państw-członków organizacji - wykonywana przez organy sądownicze organizacji międzynarodowych, jeśli taka kompetencja władcza wynika z umowy międzynarodowej (tzn. łącznie ujmowanego aktu konstytuującego organizację i umowy o akcesji), na podstawie której państwo przystąpiło do organizacji; przykładem jest jurysdykcja organów sądowniczych UE w stosunku do jej członków czy ETPCz w stosunku do państw członków Rady Europy. W tym przypadku państwo-członek jest poddane władzy sądowniczej. Szczególnym przypadkiem jest właściwość MTK, który może wykonywać jurysdykcję w stosunku do funkcjonariuszy państwa; ten przypadek jednak stanowiący element rozwoju prawa londyńskiego-norymberskiego można pozostawić poza zakresem rozważań w tej analizie, pamiętając, że karnie odpowiada jednostka zaś państwu przysługuje immunitet jurysdykcyjny.

${ }^{11}$ Patrz: Raport KPM (s. 159) „The doctrine of State immunity is the result of an interplay of two fundamental principles of international law: the principle of territoriality and the principle of State personality, both being aspects of State sovereignty. Thus, State immunity is sometimes expressed in the maxim par inparem imperium non habet", http://untreaty.un.org/ilc/publications/ yearbooks/Ybkvolumes(e)/ILC_1978_v2_p2_e.pdf. 
I uprawnione z tytułu immunitetu sądowego są oprócz państw również inne podmioty prawa międzynarodowego.

Korzenie instytucji tkwią, co dla dalszych rozważań jest istotne, w „krajowym" statusie suwerena, sukcesorem tego statusu było, a w ograniczonym m.in. w odniesieniu do niepodlegania jurysdykcji innego państwa zakresie jest dalej państwo. Jednak w stosunkach wewnętrznych status ten suweren utracił w konsekwencji ewolucji władzy od statusu cesarza-władcy absolutnego w Bizancjum będącego „najwyższym sędzią, panem administracji i wojska” czy króla Franków ${ }^{12}$ ku porządkowi państwa praworządnego. Finał ewolucji symbolizuje datowana na koniec XVIII w. legenda „o młynarzu z Sanssouci”. Zgodnie z nią Fryderyk Wielki, gdy przeszkadzał mu hałas wiatraka, zaproponował kupno młyna. Właściciel nie przyjął oferty, a na groźby monarchy wypowiedział słowa wyrażające istotę przekonania o równości wobec prawa: „(...) są jeszcze sądy w Berlinie”. Do rangi symbolu urósł fakt, że monarcha (absolutny), widząc niezachwianą wiarę poddanego w prawo ( $\mathrm{w}$ wymiar sprawiedliwości), zrezygnował z powiększenia przypałacowego parku ${ }^{13}$.

W przypadku organizacji międzynarodowych brak jest historycznych konotacji (uzasadnień), ich immunitet jurysdykcyjny w samej swojej istocie był/ jest immunitetem funkcjonalnym - miał za cel ochronę i wzmocnienie niezależności organizacji międzynarodowej w jej wewnętrznym działaniu od państwa/państw (gdyby chciały wpłynąć na działania organizacji w trybie nieregulowanym prawem - podważyć jej niezależność) ${ }^{14}$. Wskazał na to już w $1931 \mathrm{r}$. włoski Sąd Kasacyjny, uznając w sporze Profili v. Międzynarodowy Instytut Rolny brak właściwości jurysdykcyjnej wobec Instytutu jako podmiotu prawa międzynarodowego, który państwa wyposażyły w pełną autonomię w sferze wewnętrznej ${ }^{15}$.

${ }^{12}$ Szerzej J. Baszkiewicz, Powszechna historia ustrojów państwowych, Gdańsk 1998, s. 6162 i 74.

${ }_{13}$ Szerzej M. Parish, An Essay on the Accountability of International Organizations, IOLR 2010, vol. 7, no. 2, s. 18 i nast.

${ }^{14}$ Szerzej patrz: Rule of Law. International Immunity. Centre for Accountability of International Organisations, http://www.caio-ch.org/RuleofLaw.html

15, „(...) from interference by the sovereign power of the States composing the Union except when it consents thereto. Following the better and more widely held doctrine, this Supreme Court holds that the International Institute of Agriculture is such an international legal person. This being so, its power of self-determination or autonomy, which includes that of arranging its own organization and controlling the relations of the organization in their aspects both normal and exceptional rules out all States interference and all authority of its laws substantive or procedural (...). In regard to the International Institute of Agriculture any doubts of this nature must be regard as having disappeared with the granting of diplomatic immunity by the Italian Law of 20 June, 1930 (...), there is nothing which authorizes the intervention of an external jurisdiction", Rivista di diritto internazionale 1931, XXIII, s. 386 i nast.; tekst: Annual Digest of Public International Law, Case 1929-1930, International Law Reports, s. 413-415. 


\section{Uwagi wprowadzające}

Przyjęcie 2 grudnia 2004 r. Konwencji Narodów Zjednoczonych w sprawie immunitetu jurysdykcyjnego państw i ich własności ${ }^{16}$ oraz otwarcie jej - 17 stycznia 2005 r. $^{17}$ - do ratyfikacji albo przyjęcia, albo zatwierdzenia, albo przystąpienia powinno - zgodnie ze zwyczajem międzynarodowym wytworzonym wokół kodyfikacji ${ }^{18}$ prawa międzynarodowego w praktyce NZ dzięki wytworzeniu kompleksowej regulacji prawnej (złożonej - w różnej, w poszczególnych przypadkach, proporcji - z norm kodyfikujących prawo zwyczajowe jak i będących wynikiem jego rozwoju) wewnątrz, wyznaczonego zakresem kodyfikacji, działu prawa międzynarodowego - zamknąć w istotnym zakresie (potencjalne(?) - wszelkie(?)) kontrowersje dotyczące immunitetu jurysdykcyjnego państwa, a przede wszystkim wytworzyć powszechnie akceptowaną interpretację przedmiotowo istotnych norm $^{19}$. Oczywiście nastąpi to, jeśli w ogóle nastąpi, dopiero po wejściu Konwencji w życie, czyli w 30 dniu po spełnieniu wymogu minimalnej liczby ratyfikacji.

${ }^{16}$ Tekst: United Nations Convention on Jurisdictional Immunities of States and Their Property 2004; http://untreaty.un.org/ilc/texts/instruments/english/conventions/4_1_2004.pdf. Patrz również: Komentarz do Konwencji: Draft Articles on Jurisdictional Immunities of States and their Property, with commentaries 1991; http://untreaty.un.org/ilc/texts/instruments/english/commentaries/4_1_1991.pdf.

${ }_{17}$ Konwencję dotychczas podpisało 19 państw: Belgia (22.04.2005), Chiny (14.09.2005), Czechy (13.10.2006), Dania (19.09.2006), Estonia (30.03.2006), Finlandia (14.09.2005), Francja (17.01.2007), Indie (12.01.2007), Islandia (16.09.2005), Madagaskar (15.09.2005), Maroko (17.01.2005), Meksyk (25.09.2006), Paragwaj (16.09.2005), Rosja (01.12.2006), Senegal (21.09.2005), Sierra Leone (21.09.2006), Słowacja (15.09.2005), Timor (16.09.2005), Wielka Brytania (30.09.2005).

Ratyfikowało zaś tylko/aż(?) 11: Austria (14.09.2006, podpisała 17.01.2006), Arabia Saudyjska (01.09.2010), Iran (29.09.2008, podpisał 17.01.2007), Japonia (11.05.2010, podpisała 11.01.2007), Kazachstan (17.02.2010), Liban (21.11.2008, podpisał 11.11.2005), Norwegia (27.03.2006, podpisała 08.07.2005), Portugalia (14.09.2006, podpisała 25.02.2005), Rumunia (15.02.2007, podpisała 14.09.2005), Szwajcaria (16.04.2010, podpisała 19.09.2006), Szwecja (23.12.2009, podpisała 14.09.2005).

${ }^{18}$ Posługuję się terminem kodyfikacja w dwóch różnych znaczeniach tzn. zarówno ścisłym (prawnym i prawniczym), kodyfikacja - nadanie formy traktatowej obowiązującym normom prawa zwyczajowego (np. część norm KPT); jak i potocznym, kodyfikacja - każdorazowy wynik prac nad wytworzeniem traktatowej regulacji uniwersalnej w systemie instytucjonalnym ONZ (skrajnym przykładem posługiwania się terminem w tym rozumieniu jest zwrot ,(...) kodyfikacja reżimu NPT”). O znaczeniu użytego w konkretnym przypadku terminu decyduje kontekst.

19 Oczekiwanie to (,Stressing the importance of uniformity and clarity in the law of jurisdictional immunities of States and their property, and emphasizing the role of a convention in this regard") potwierdziło Zgromadzenie Ogólne w rezolucji A/RES/59/38 z 16 grudnia 2004 r. i Preambuła Konwencji (,Believing that an international convention on the jurisdictional immunities of States and their property would enhance the rule of law and legal certainty, particularly in dealings of States with natural or juridical persons, and would Contribute to the codification and development of international law and the harmonization of practice in this area"). 
Miały, co prawda, miejsce również odstępstwa od tej procedury standardowej w przypadkach, w których uznawano, że normy skodyfikowane obowiązują jako normy prawa zwyczajowego lub gdy postrzegano je jako acquis w międzynarodowym porządku prawnym ${ }^{20}$, jednak w odniesieniu do tej Konwencji państwa zadecydowały o nieskorzystaniu z formuły acquis, zaś jej normy nie kodyfikują, bez wątpienia, prawa zwyczajowego (o tym dalej).

Zakończenie prac nad Konwencją Narodów Zjednoczonych w sprawie immunitetu jurysdykcyjnego państw i ich własności powinno (powinność ma w odniesieniu do tego przypadku charakter zwyczaju) zarazem zapoczątkować kodyfikacje kolejne $\mathrm{w}$ tym dziale prawa ${ }^{21}$. Przede wszystkim, bo takie jest powtarzalne doświadczenie ${ }^{22}$, kodyfikację immunitetu jurysdykcyjnego organizacji międzynarodowych i ich własności.

Ta oczekiwana i pożądana prawidłowość (serii kodyfikacji wewnątrz działu) potwierdza się w przypadku kodyfikacji i stopniowego rozwoju immunitetu jurysdykcyjnego tylko częściowo. W Komisji Prawa Międzynarodowego trwają prace m.in. nad projektem konwencji regulującej immunitet funkcjonariuszy państwa w odniesieniu do zagranicznej jurysdykcji karnej. Brak jest jednak zapowiedzi kodyfikacji immunitetu jurysdykcyjnego organizacji międzynarodowych i ich własności; można oczywiście uznać materię immunitetu jurysdykcyjnego organizacji międzynarodowych i ich własności za skodyfikowaną (tyle, że w wielu tekstach międzynarodowych).

To nie jedyne odstępstwo od wskazanego, sui generis, zwyczajowego standardu oenzetowskiego prawotwórstwa, również nie jest to odstępstwo o największym ciężarze gatunkowym - najpoważniejsze w skali zagrożeń. Również w innych zakresach prawniczej analizy tej legislacji trudno ocenić, że sytuacja po kodyfikacji materii immunitetu jurysdykcyjnego państw i ich własności mieści się w ramach zwyczaju.

Można wyrażać istotne wątpliwości zarówno w odniesieniu do treści przyjętych uregulowań, jak i ich interpretacji, obawiać się można, że kolejne - co będzie jednak już wątpliwym sukcesem kodyfikacji - ujawni praktyka. Można nawet poddać w wątpliwość poziom legislacyjny Konwencji, np. przeniesienie/ umieszczenie w Aneksie regulacji merytorycznie istotnych trudno uznać za praktykę pożądaną.

${ }^{20} \mathrm{Za}$ autora terminu w tym kontekście można uznać Crowforda. Szerzej patrz: J. Menkes, Artykut 53 Konwencji wiedeńskiej o prawie traktatów - kodyfikacja czy rozwój?, [w:] Z. Galicki, T. Kaminski, K. Myszona-Kostrzewa, 40 lat minęto - praktyka i perspektywy Konwencji wiedeńskiej o prawie traktatów, Warszawa 2009, s. 150-154, również idem, Stopniowy rozwój prawa odpowiedzialności organizacji międzynarodowych - wybrane problemy, [w:] A. Kozłowski, B. Mielnik (red.), Odpowiedzialność międzynarodowa jako element międzynarodowego porzadku prawnego, Wrocław 2009, s. 268 i 269.

${ }^{21}$ Wzorcem i punktem odniesienia jest w tym zakresie oczywiście prawo traktatów i prawo przestrzeni międzynarodowych.

${ }^{22}$ Miała miejsce praktyka najpierw wydzielania z przedmiotowego zakresu objętego legislacją norm ze względu na podmiot-adresata regulacji po to, by kolejno podjąć działania zmierzające do objęcia kolejną konwencją podmioty wyłączone z zakresu regulacji pierwszej konwencji. 
Bez wątpienia cechą szczególną Konwencji Narodów Zjednoczonych w sprawie immunitetu jurysdykcyjnego państw i ich własności jest proporcja wewnętrzna pomiędzy kodyfikacją a rozwojem - pomiędzy (kolokwialnie rzecz ujmując) starymi a nowymi normami. Jest bowiem niewątpliwą i dobrą praktyką, w ramach której najpierw sprawozdawcy, KPM, a ostatecznie państwa w oenzetowskich konwencjach łączą „dwa w jednym” tzn. i kodyfikują zwyczaj, i tworzą nowe normy. To, jak się wydaje, decyduje o sensie tworzenia konwencji; społeczność międzynarodowa niewątpliwie potrzebuje i spisania norm prawa zwyczajowego (gdyż zarówno ułatwia to poznanie prawa na potrzeby jego stosowania, jak i usuwa - ewentualne - niejasności i różnice), i tworzenia nowego prawa w odpowiedzi na jego brak (wobec „starego" zapotrzebowania i wobec nowych potrzeb) ${ }^{23}$.

Zasadne jest więc postawienie w odniesieniu do przypadku immunitetu jurysdykcyjnego państwa i jego własności oraz innych (niż państwo) podmiotów, w tym przede wszystkim międzyrządowych organizacji międzynarodowych, pytania, czy kodyfikacja - nadanie formy traktatu prawu zwyczajowemu w tym konkretnym przypadku było/byłoby konieczne, a przynajmniej racjonalne i możliwe? Jednoznaczna odpowiedź na to pytanie brzmi: nie.

Wbrew zabiegom semantycznym przypisującym dwóm zakresom treści normy regulującej immunitet jurysdykcyjny państwa tzn. absolutnemu i ograniczonemu cechy sekwencyjności: immunitet absolutny - klasyczny, immunitet ograniczony - nowa praktyka nie wskazuje ani na istnienie (kiedykolwiek) jednolitej normy prawa zwyczajowego, ani na jej zmianę - zawężania zakresu immunitetu. Na podstawie praktyki nie można jednoznacznie stwierdzić, czy zawężony został immunitet jurysdykcyjny - absolutny do zakresu ograniczonego, czy to nowe formy działalności państwa nie zostały objęte immunitetem; czy klasyczny jest więc immunitet absolutny ${ }^{24}$, czy klasyczne są wyłącznie działania iure imperii ${ }^{25}$.

${ }^{23}$ Kwestia ta jest wystarczająco omówiona w oficjalnej informacji o Komisji Prawa Międzynarodowego patrz: Origin and background of the development and codification of international law, http://www.un.org/law/ilc/

24 J. B. Tate (Acting Legal Adviser) w dokumencie z 19 maja 1952 r., zwanym „Tate Letter”, skierowanym do P. B. Perlman (Acting Attorney General) wskazał, że „The classical or virtually absolute theory of sovereign immunity has generally been followed by the courts of the United States, the British Commonwealth, Czechoslovakia, Estonia, and probably Poland.

The decisions of the courts of Brazil, Chile, China, Hungary, Japan, Luxembourg, Norway, and Portugal may be deemed to support the classical theory of immunity if one or at most two old decisions anterior to the development of the restrictive theory may be considered sufficient on which to base a conclusion.

The position of the Netherlands, Sweden, and Argentina is less clear since although immunity has been granted in recent cases coming before the courts of those countries, the facts were such that immunity would have been granted under either the absolute or restrictive theory. However, constant references by the courts of these three countries to the distinction between public and private acts of the state, even though the distinction was not involved in the result of the case, may indicate an intention to leave the way open for a possible application of the restrictive theory of immunity if and when the occasion presents itself. 
Równie uprawnione były dwa różne kierunki legislacji albo nadanie uniwersalnego charakteru praktyce sankcjonującej absolutnym immunitet jurysdykcyjny państwa i innych podmiotów (jednak w tym przypadku spisywanie prostego

A trend to the restrictive theory is already evident in the Netherlands where the lower courts have started to apply that theory following a Supreme Court decision to the effect that immunity would have been applicable in the case under consideration under either theory.

The German courts, after a period of hesitation at the end of the nineteenth century have held to the classical theory, but it should be noted that the refusal of the Supreme Court in 1921 to yield to pressure by the lower courts for the newer theory was based on the view that that theory had not yet developed sufficiently to justify a change. In view of the growth of the restrictive [425 U.S. $682,713]$ theory since that time the German courts might take a different view today.

The newer or restrictive theory of sovereign immunity has always been supported by the courts of Belgium and Italy. It was adopted in turn by the courts of Egypt and of Switzerland. In addition, the courts of France, Austria, and Greece, which were traditionally supporters of the classical theory, reversed their position in the 20's to embrace the restrictive theory. Rumania, Peru, and possibly Denmark also appear to follow this theory.

Furthermore, it should be observed that in most of the countries still following the classical theory there is a school of influential writers favoring the restrictive theory and the views of writers, at least in civil law countries, are a major factor in the development of the law. Moreover, the leanings of the lower courts in civil law countries are more significant in shaping the law than they are in common law countries where the rule of precedent prevails and the trend in these lower courts is to the restrictive theory.

Of related interest to this question is the fact that ten of the thirteen countries which have been classified above as supporters of the classical theory have ratified the Brussels Convention of 1926 under which immunity for government owned merchant vessels is waived. In addition the United States, which is not a party to the Convention, some years ago announced and has since followed, a policy of not claiming immunity for its public owned or operated merchant vessels. Keeping in mind the importance played by cases involving public vessels in the field of sovereign immunity, it is thus noteworthy that these ten countries (Brazil, Chile, Estonia, Germany, Hungary, Netherlands, Norway, Poland, Portugal, Sweden) and the United States have already relinquished by treaty or in practice an important part of the immunity which they claim under the classical theory [425 U.S. 682, 714].

It is thus evident that with the possible exception of the United Kingdom little support has been found except on the part of the Soviet Union and its satellites for continued full acceptance of the absolute theory of sovereign immunity. There are evidences that British authorities are aware of its deficiencies and ready for a change. The reasons which obviously motivate state trading countries in adhering to the theory with perhaps increasing rigidity are most persuasive that the United States should change its policy. Furthermore, the granting of sovereign immunity to foreign governments in the courts of the United States is most inconsistent with the action of the Government of the United States in subjecting itself to suit in these same courts in both contract and tort and with its long established policy of not claiming immunity in foreign jurisdictions for its merchant vessels. Finally, the Department feels that the widespread and increasing practice on the part of governments of engaging in commercial activities makes necessary a practice which will enable persons doing business with them to have their rights determined in the courts. For these reasons it will hereafter be the Department's policy to follow the restrictive theory of sovereign immunity in the consideration of requests of foreign governments for a grant of sovereign immunity", http://caselaw.lp.findlaw. $\mathrm{com} /$ scripts/getcase.pl? court $=$ US\&vol $=425 \&$ invol $=682$

Ta jednoznaczna, a tak istotna dla przedmiotowych rozważań analiza praktyki nie została nigdy podważona.

${ }^{25}$ Podstawą podziału jest doktryna ,act of State”, która była analizowana w sprawie Banco Nacional de Cuba v. Sabbatino, a wcześniej m.in. w Underhill v. Hernandez czy Oetjen v. Central Leather Co; szerzej H. J. Steiner, D. F. Vagts, H. Hongju Koh, op. cit., s. 780-819. 
przepisu - jednozdaniowej normy trudno byłoby uznać za zachowanie racjonalne) albo takiż zabieg w odniesieniu do immunitetu ograniczonego (z wyznaczeniem podstaw ograniczenia). Materia immunitetu jurysdykcyjnego państwa i jego własności zostały poddane kodyfikacji, ponieważ niektóre(!) (dalece nie wszystkie) państwa chciały usankcjonować zmiany w prawie wewnętrznym (USA ${ }^{26}$ i Wielka Brytania $^{27}$ ), niektóre nadać charakter uniwersalny praktyce własnej (Europa ${ }^{28}$ ), ponieważ istniał/istnieje spór nie tylko pomiędzy podmiotami prawa międzynarodowego, ale i innymi aktorami międzynarodowymi o treść i zakres immunitetów międzynarodowych (bo nie tylko jurysdykcyjnego) i uprawnionych z jego tytułu.

Spór cechuje się zmienną, jednak stale wysoką dynamiką, angażuje w znaczącym stopniu zainteresowanie opinii społecznej i dotyka kwestii pytań fundamentalnych. $\mathrm{Z}$ jednej strony mamy do czynienia, częściowo, z obroną zdolności do działania w stosunkach międzynarodowych - prawem uznającym za wartość wzgląd na funkcjonalizm (obrona immunitetu), z drugiej strony mamy do czynienia z prawem/postulatem odwołującym się do aksjologii moralnej, tzn. równości wobec prawa (co najmniej ograniczenie immunitetu). Wyostrzając, można podnosić albo że immunitet ograniczony zagraża obrotowi, albo że immunitet absolutny zagraża prawu (wartościom z nim utożsamianym, takim jak równość i pewność stosowania ${ }^{29}$. Jednak nie podlega wątpliwości, że stan wytworzony w wyniku przyjęcia Konwencji Narodów Zjednoczonych i niewejścia jej (dotychczas) w życie jest szczególnie zły. Negliżuje bowiem zarówno brak uniwersalnego reżimu immunitetu jurysdykcyjnego państwa (i innych podmiotów prawa międzynarodowego) i ich własności, jak i niedążenie do wytworzenia

${ }^{26}$ Mocą Sekcji 1604 z Foreign Sovereign Immunities Act z 1976 r. „,Subject to existing international agreements, to which the United States is a party at the time of enactment of this Act a foreign State shall be immune from the jurisdiction of the courts of the United States and of the States except as provided in sections 1605 to 1607 of this chapter".

${ }_{27}$ Zgodnie z artykułem 1 State Immunity Act z 1978 r. „1. (1) A State is immune from jurisdiction of the courts of the United Kingdom except as provided in the following provisions of this part of this Act. (2) A court shall give effect to the immunity conferred by this Section even though the State does not appear in the proceedings in question".

28 „Zważywszy na fakt, że w prawie międzynarodowym istnieje tendencja do zawężania przypadków (podkr. - J. M.), w których Państwo może powoływać się na immunitet wobec obcych sądów". Konwencja europejska z 1972 r. (European Convention on State Immunity, Bazel 16.05.1972).

${ }^{29}$ Tak KPM w Raporcie KPM (s. 159) „'2 Jurisdictional immunities of States and their property' is clearly a topic of public international law affecting the rights, interests and duties of States as well as of private persons, inasmuch as conflicts and disputes may arise from the intercourse and transactions between foreign States and private persons. 13. The topic is of interest to States broadly from two opposing standpoints: States as territorial sovereigns for the exercise of their sovereign authority over the entirety of their territorial units, and States as foreign sovereigns being impleaded or pursued in litigation or suits by individual or corporate plaintiffs before the judicial or administrative authorities of another State exercising territorial jurisdiction over cases involving foreign States", http://untreaty.un.org/ilc/publications/yearbooks/Ybkvolumes(e)/ILC_1978_v2_p2_e.pdf. 
powszechnego standardu. Protagoniści kierunku legislacji - ograniczonego immunitetu jurysdykcyjnego, który odzwierciedla Konwencja, udowodnili swoją siłę-możliwości(?), jednak nie doprowadzili do ostatecznego zwycięstwa, tzn. wejścia w życie Konwencji. Mało tego, żaden ze stałych członków Rady Bezpieczeństwa nie ratyfikował Konwencji, tylko 4 z 5 z nich ją podpisało ${ }^{30}$, jednak główny - jak mogłoby się wydawać - zwolennik kierunku kodyfikacji USA nie uczyniły nawet tego. Zachowanie USA oznaczać może albo niewiarę w sukces tzn. wejście Konwencji w życie, albo nastawienie na działania unilateralne w odniesieniu do immunitetu jurysdykcyjnego podmiotów prawa międzynarodowego i ich własności, albo szersze: negatywne nastawienie do legislacji międzynarodowych $\mathrm{w}$ formule instytucjonalnej $\mathrm{ONZ}^{31}$.

\section{a. Antecedencje odejścia od immunitetu absolutnego}

Rzeczą oczywistą jest, że idea ograniczenia immunitetu jurysdykcyjnego państwa nie pojawiła się niczym deus ex machina w II połowie XX w. Absolutny immunitet jurysdykcyjny państwa został w sposób istotny podważony już przez Instytut Prawa Międzynarodowego na sesji w Cambridge 1895 r. ${ }^{32}$ Decydującym argumentem na rzecz zmian były jednak procesy, które miały miejsce w wieku XX; podjęcie przez państwa o gospodarce niewolnorynkowej (zwanej: centralnie planowaną) zawodowej działalności (produkcyjnej i handlowej) nastawionej na zysk, w której państwa chciały zarówno korzystać z wszystkich uprawnień osoby prawnej w obrocie handlowym, jak i być chronione immunitetem jurysdykcyjnym państwa przed odpowiedzialnością z tytułu uczestnictwa $\mathrm{w}$ tym obrocie. Jednak obecnie

${ }^{30}$ Trudno o jednoznaczną prognozę konsekwencji złożenia przez Chiny i Rosję podpisów pod Konwencją. Może to być bowiem zapowiedź, że państwa te zmieniły ostatecznie swoje stanowisko i akceptują ograniczenie immunitetu w zakresie wyznaczonym Konwencją, może to być jednak również gest polityczny - dowód postawy nastawionej na współpracę generalnie, jednak nieprzekładający się w tym konkretnym przypadku na ratyfikację.

${ }^{31}$ Można bowiem w tym przypadku zarówno dostrzegać kontynuację/ciągłość amerykańskiej praktyki zademonstrowanej w odniesieniu do Konwencji w sprawie zapobiegania i karania zbrodni ludobójstwa i Statutu rzymskiego MTK, jak i traktować ten przypadek jako zdecydowanie odrębny.

32 Patrz: ograniczenia artykułu $16 \mathrm{w}$ odniesieniu do regulacji generalnej Règlement sur les immunités diplomatiques „L'immunité de juridiction ne peut être invoquée:

$1^{\circ}$ En cas de poursuites exercées à raison d'engagements contractés par la personne exempte, non en sa qualité officielle ou privée, mais dans l'exercice d'une profession exercée par elle dans le pays concurremment avec ses fonctions diplomatiques;

$2^{\circ}$ En matière d'actions réelles, y compris les actions possessoires, se rapportant à une chose,meuble ou immeuble, qui se trouve sur le territoire.

Elle subsiste, même en cas de contravention dangereuse pour l'ordre ou la sécurité publique ou de crime attentatoire à la sûreté de l'État, sans préjudice du droit pour le gouvernement territorial de prendre telles mesures conservatoires qu'il appartiendra (art. 6, 3º)", http://www.idi-iil.org/idiF/ resolutionsF/1895_camb_01_fr.pdf. 
te problemy i zjawiska, nawet jeśli nie mają wyłącznie charakteru historycznego, to nie na nich koncentruje się uwaga opinii publicznej i nie one są powodem zdecydowanego podważania norm składających się na immunitet jurysdykcyjny podmiotów prawa międzynarodowego. W centrum zainteresowania znajdują się przypadki nadużycia immunitetu, głównie zresztą dyplomatycznego, o charakterze kryminalnym z udziałem zarówno państw - ich przedstawicieli dyplomatycznych, jak i organizacji międzynarodowych - funkcjonariuszy międzynarodowych. Ze zdecydowanym sprzeciwem spotykają się przypadki zdarzeń o różnym ciężarze gatunkowym ${ }^{33}$, składające się jednak na jednolity obraz nadużyć prawa ${ }^{34}$ : - skandale „Oil for Food" 35 i „Sex for Food”36; - ochrona przed postawieniem (w 1983 r.) syna dyplomaty akredytowanego w USA w stan oskarżenia pod zarzutem 15 gwałtów; - nadużycia seksualne Wysokiego Komisarza NZ ds. uchodźców Ruud Lubbers ${ }^{37}$; - unikanie na dużą skalę wykonywania zobowiązań z tytułu długów, alimentów i świadczeń rodzinnych ${ }^{38}$ (o skali i powadze zjawiska świadczy fakt, że było ono przedmiotem dyskusji w trakcie IV Światowej Konferencji NZ nt. kobiet w 1995 r. w Pekinie) ${ }^{39}$; - zabójstwo, strzałem z okna ambasady libijskiej w Londynie (1984 r.), policjantki Yvonne Fletcher ${ }^{40}$; - stwarzanie poważnego zagrożenia i wypadków w ruchu drogowym, które ilustruje określenie autostrady w okolicy Bonn „Diplomatenrennbahn” czy wypadki ze skutkiem śmiertelnym zawinione przez dyplomatów (rumuńskiego - Silviu Ionescu, gruzińskiego - Geuorgui Makharadze, rosyjskiego - Andrei Knyazev czy amerykańskiego - Douglas Kent); - pogarda dla prawa - niepłacenie za parkowanie ${ }^{41}$.

${ }^{33}$ Świadomie przywołuję jednak wyłącznie przypadki mające jednoznacznie kryminalny wymiar.

${ }^{34}$ Szerzej E. P. Flaherty, The Abuse of Functional Immunity Party Almost Over Last Chance, Last Call?, UN Special 2003 Archvie July-August 2003, no. 620; również M. Parish, op. cit., s. 6 i nast.

${ }_{35}$ Nadużycia ujawnione w Raporcie Volckera obciążały imiennie Sekretarza Generalnego ONZ Kofi A. Annana, ale również Organizację. Początek ujawnieniu przestępstw dało śledztwo wszczęte w 2005 r. przez Roberta Morgenthau'a które objęło wysokiego funkcjonariusza ONZ Benona Sevana (obywatela cypryjskiego); szerzej K. Anderson, Legal Accountability of International Organizations and Their Agents, Opinio Juris December 28th, 2010, http://opiniojuris. org/2010/09/16/legal-accountability-of-international-organizations-and-their-agents/

${ }_{36}$ Terminem tym określa się serię przestępstw-skandali, w których osoby zatrudnione przez UNHCR w Sierra Leone, Liberii i Gwinei w zamian za żywność dopuszczały się przestępstw seksualnych (m.in. gwałtów) przeciwko młodym kobietom - uchodźcom.

37 Szerzej P. Goodenough, U.N. Employees Seek U.S. Supreme Court Ruling on Immunity for Top Officials, Thursday, March 04.2010, http://www.cnsnews.com/node/62254

${ }^{38}$ Do rangi symbolu urosły sprawy Barbara Elzohairy (żony przedstawiciela Egiptu przy ONZ) czy Fernandez v. Fernandez (na tle rozwódu obywatelki USA z przedstawicielem Mozambiku przy ONZ).

39 Szerzej patrz: hasło „Diplomatic Immunity”, West’s Encyclopedia of American Law 2005, http://www.encyclopedia.com/doc/1G2-3437701403.html

40 Patrz: B. Bailey, Police condemn Libya trial for Yvonne Fletcher killer, „London Evening Standard", 14 Sep. 2009.

${ }^{41}$ W lutym 1995 r. Burmistrz Nowego Jorku Rudolph Giuliani ujawnił zaległości dyplomatów na kwotę 800000 USD. 


\section{b. Kolejne kroki}

Jeśli już jednak stworzono (tzn. Konwencję) ten pierwszy krok - nie wiadomo oczywiście, czy ku wytworzeniu nowego, uniwersalnego porządku normatywnego w odniesieniu do immunitetu, czy ku ujawnieniu i pogłębieniu różnic standardów prawnych pomiędzy państwami to nie sposób na tym pierwszym kroku - tzn. regulacji dookreślonej podmiotowo - poprzestać. Inne niż państwa podmioty prawa międzynarodowego publicznego tzn. międzyrządowe organizacje międzynarodowe i pozarządowe organizacje międzynarodowe potrzebują kodyfikacji (sobie właściwego) immunitetu jurysdykcyjnego i ich własności tak samo jak państwa, tylko że bardziej $^{42}$. Potrzebują również kodyfikacji pozostałych immunitetów ${ }^{43}$ i odpowiedzi na pytanie, czy ich immunitet jurysdykcyjny (acz nie tylko) może być różny zakresem, co w tym przypadku oznacza szerszy od immunitetu jurysdykcyjnego państwa. O skali wyzwania (dla każdego państwa, ale i dla całej społeczności międzynarodowej, a także dla każdej organizacji międzynarodowej) decyduje liczba funkcjonujących (w poszczególnych państwach ${ }^{44}$ ) organizacji międzynarodowych i dynamika procesu obejmowania kolejnych immunitetami, w tym jurysdykcyjnym ${ }^{45}$.

\section{c. Ile kodyfikacji? Ile stopniowego rozwoju?}

Proporcja starego i nowego jest w przypadku każdej kodyfikacji różna, co nie dziwi, jest również faktem, że państwa różnie przyporządkowują normy składające się na (konkretną) konwencję - co już dziwi, ale przede wszystkim powinno skłaniać do odczuwania zaniepokojenia ${ }^{46}$.

${ }^{42}$ Pogląd zbieżny E. Gaillard, I. Pingel-Lenuzza, International Organizations and Immunity from Jurisdiction: to restrict or to bypass, ICLQ 2002, vol. 51, Part 1, s. 1-15.

${ }^{43} \mathrm{~W}$ odniesieniu do państw KPM prowadzi odnośne prace kodyfikacyjne.

${ }^{44}$ Szacuje się, że w USA uprawnionych z tytułu IOIA jest 75 organizacji międzynarodowych, wśród nich nie tylko powszechnie znane, np. organizacje Systemu NZ czy MKCK, ale tak ,egzotyczne”, jak Międzynarodowa Komisja Halibuta Pacyficznego, Międzyamerykańska Komisja Tuńczyka czy Światowy Fundusz do Walki z AIDS, Gruźlicą i Malarią. W Genewie stale przebywa i pracuje ca 25000 funkcjonariuszy międzynarodowych, z czego ponad $60 \%$ jest zatrudnionych na krótkoterminowych (3-6 m-ce) kontraktach.

${ }^{45}$ Przykładem jest status INTERPOL-u, który najpierw Prezydent Reagan uznał za publiczną organizację międzynarodową (Executive Order No. 12425 z 16.06.1983), kolejno Prezydent Clinton zwolnił z opłat celnych i przyznał prawo do zwrotu podatków (Executive Order No. 12971 z 09.1995), by ostatecznie (17.12.2009) przez Prezydenta Obamę został zwolniony z wszelkich ograniczeń w korzystaniu z IOIA.

W skłonności do rozszerzania listy uprawnionych z tytułu IOIA na kolejne organizacje brak różnic pomiędzy prezydentami demokratycznymi a republikańskimi.

${ }^{46}$ Przykładem wyrazistym jest klasyfikacja kategorii ius cogens w Konwencji wiedeńskiej o prawie traktatów; szerzej J. Menkes, op. cit., s. 147-168; patrz również: A. Gubrynowicz, Ile kodyfikacji, ile postępowego rozwoju, czy konwencja wiedeńska jest „, przestarzała”?, ibidem, s. 121-146. 
Otóż, w mojej ocenie, w przypadku Konwencji Narodów Zjednoczonych w sprawie immunitetu jurysdykcyjnego państw i ich własności za kodyfikację można uznać, w najlepszym przypadku, jej artykuł 5 ,State immunity. A State enjoys immunity, in respect of itself and its property, from the jurisdiction of the courts of another State subject to the provisions of the present articles". Ocena ta ma za podstawę również bezpośredni przebieg prac nad wskazanym artykułem 5 Konwencji, w trakcie których zrezygnowano z zamiaru, by podstawą ograniczenia immunitetu były nie tylko regulacje samej Konwencji, lecz także i prawo międzynarodowe ${ }^{47}$. Zarazem jednak uznano, że nawet tak podstawowy dla Konwencji, a zarazem niezdefiniowany termin musi zostać jednak dookreślony, co dokonano w Aneksie do Konwencji, stwierdzając „With respect to article 10 the term 'immunity' in article 10 is to be understood in the context of the present Convention as a whole. Article 10, paragraph 3, does not prejudge the question of 'piercing the corporate veil', questions relating to a situation where a State entity has deliberately misrepresented its financial position or subsequently reduced its assets to avoid satisfying a claim, or other related issues". Reszta jest już rozwojem, co bynajmniej per se nie jest wadą Konwencji (ani tej ani jakiejkolwiek innej) i czego Komisja Prawa Międzynarodowego nie ukrywa w Komentarzu ${ }^{48}$. Podnieść można co najwyżej zarzut nieadekwatności tytułu legislacji w stosunku do objętej nią materii, gdyż adekwatnym tytułem dla konwencji byłby bowiem tytuł: (...) konwencja w sprawie ograniczeń immunitetu jurysdykcyjnego państw i ich własności. Oczywiście można się zastanawiać, czy państwa dobrze skorzystały z możliwości do tworzenia nowego prawa w relacji z prawem obowiązującym(?). Odpowiedzi na to pytanie dostarczy rzecz jasna dopiero przyszłość, decydujący będzie dla udzielenia odpowiedzi na to pytanie bowiem czas, ten, który upłynie do wejścia w życie Konwencji w wyniku jej ratyfikacji, i zasięg (liczba

${ }^{47}$ Dyskutowana była koncepcja, w ramach której (w starej numeracji tzn. Artykuł 6) „A State enjoys immunity, in respect of itself and its property, from the jurisdiction of the courts of another State subject to the provisions of the present articles (and the relevant rules of general international law - podkr. J. M.)", http://untreaty.un.org/ilc/publications/yearbooks/Ybkvolumes(e)/ILC_1989_ v2_p2_e.pdf.

${ }^{48}$, ,(2) The formulation of article 5, which expresses the main principle of State immunity, has been difficult, as it is a delicate matter. Legal theories abound as to the exact nature and basis of immunity. There is common agreement that for acts performed in the exercise of the prerogatives de la puissance publique or 'sovereign authority of the State', there is undisputed immunity. Beyond or around the hard core of immunity, there appears to be a grey area in which opinions and existing case law and, indeed, legislation still vary. Some of these indicate that immunity constitutes an exception to the principle of territorial sovereignty of the State of the forum and as such should be substantiated in each case. Others refer to State immunity as a general rule or general principle of international law. This rule is not absolute in any event since even the most unqualified of all the theories of immunity admits one important exception, namely, consent, which also forms the basis for other principles of international law. Others still adhere to the theory that the rule of State immunity is a unitary rule and is inherently subject to existing limitations. Both immunity and non-immunity are part of the same rule. In other words, immunity exists together with its innate qualifications and limitations". 
i ranga państw) ratyfikacji. Nie można bowiem zlekceważyć ani faktu istotnego zróżnicowania stanowisk prawnych państw w stosunku do przyjętych rozwiązań już na etapie wstępnej dyskusji i projektowania ${ }^{49}$, ani obiektywnej nowości przyjętych rozwiązań nawet w ramach oficjalnego stanowiska prawnego głównych promotorów ${ }^{50}$. Państwa członkowskie Rady Europy wskazały ten fakt, wyraź-

${ }^{49} \mathrm{~W}$ ankiecie Sekretarza Generalnego ONZ na pytania związane z immunitetem jurysdykcyjnym państw odpowiedziała zdecydowana mniejszość członków Organizacji, również zdecydowana mniejszość publikuje systematycznie orzecznictwo krajowe. Tak więc nie sposób powiedzieć, jakie są/były poglądy prawne państw, jednak, co zdecydowanie ważniejsze, istniała przez cały okres prac w tej nielicznej podgrupie (której poglądy były znane) istotna różnica stanowisk - podział na zwolenników immunitetu absolutnego i jego ograniczeń; szerzej patrz: R. Sonnenfeld, Immunitet państwa a obecne i przewidywane problemy międzynarodowoprawne stosunków Polski z głównymi państwami kapitalistycznymi, PISM, Warszawa 1989, s. 4 i 5.

${ }^{50} \mathrm{~W}$ przypadku USA punkt wyjścia tej rewolucji odzwierciedla wyartykułowanie, w $1812 \mathrm{r}$., przez Sędziego Sądu Najwyższego Marshalla doktryny absolutnego immunitetu jurysdykcyjnego państwa, a jej przebieg na osi czasu wyznacza z jednej strony stanowisko Sądu Najwyższego z 1926 r. w sprawie Berrizzi Brothers Co. v. S.S. Pesaro, z drugiej zaś stanowisko departamentu Stanu z 1952 r. sformułowane w Tate Letter: „According to the newer or restrictive theory of sovereign immunity, the immunity of the sovereign is recognized with regard to sovereign or public acts (jure imperii) of a state, but not with respect to private acts (jure gestionis) (...). $[\mathrm{T}]$ he Department feels that the widespread and increasing practice on the part of governments of engaging in commercial activities makes necessary a practice which will enable persons doing business with them to have their rights determined in the courts. For these reasons it will hereafter be te Department's policy to follow the restrictive theory of sovereign immunity in the consideration of requests of foreign governments for a grant of sovereign immunity. (...) It is realized that a shift in policy by the executive cannot control the courts but is felt that the counes are leas likely to allow a plea of sovereign immunity where the executive has declined to do so. There have been indications that at least some Justices of the Supreme Court feel that in this matter courts should follow the branch of the Government charged with responsibility for the conduct of foreign relations (...)" (szerzej patrz: L. M. Drachsle, Some Observations on the Current Status of the Tate Letter, „The American Journal of International Law” 1960, vol. 54, no. 4, s. 790-800). Tę rewolucję odnotował Sąd Najwyższy w sprawie Republic of Austria et. A., Petitioners Maria v. Altman, stwierdzając , ,...) the legal concept of sovereign immunity, as traditionally applied, is about a defendant's status at the time of suit, not about a defendant's conduct before the suit. Thus King Farouk's sovereign status permitted him to ignore Christian Dior's payment demand for 11 'frocks and coats' bought (while king) for his wife; but once the king lost his royal status, Christian Dior could sue and collect (for clothes sold before the abdication). See Ex-King Farouk of Egypt v. Christian Dior, 84 Clunet 717, 24 I. L. R. 228, 229 (CA Paris 1957) (Christian Dior 'is entitled (...) to bring' the ex-King to court 'to answer for debts contracted' before his abdication 'when, as from the date of his abdication, he is no longer entitled to claim (...) immunity' as 'Hea[d] of State'); see also Queen v. Bow Street Metropolitan Stipendiary Magistrate (Ex parte Pinochet Ugarte), 1 App. Cas. 147, 201-202 (1999) (opinion of Lord Browne-Wilkinson) ('[T] he head of state is entitled to the same immunity as the state itself (...). He too loses immunity ratione personae on ceasing to be head of state'); cf. Ter K. v. The Netherlands, Surinam \& Indonesia, 18 I. L. R. 223 (DC Hague 1951) (affording Indonesia sovereign immunity after it became independent while the suit was pending). Indeed, just last Term, we unanimously reaffirmed this classic principle when we held that a now-private corporation could not assert sovereign immunity, even though the events in question took place while a foreign government was its owner. 
nie stwierdzając: „Zważywszy na fakt, że w prawie międzynarodowym istnieje tendencja do zawężania przypadków, w których Państwo może powoływać się na immunitet wobec obcych sądów" 51 . Zakończono kodyfikację, co może oznaczać albo sukces (usunięcie różnic w regulacjach prawnych pomiędzy państwami zapobiegające potencjalnym kontrowersjom na tle respektowania albo odmowy respektowania immunitetu państwa i jego własności - i ta ocena jest niezależna od oceny aksjologii), albo niepowodzenie (utrzymanie różnic ${ }^{52}$ - niewejście w życie Konwencji lub jej ograniczony zasięg i polityczną trudność w powrocie do prac nad kodyfikacją - ich ponowne podjęcie).

Pośrednim dowodem, że kodyfikacja nie zaowocowała w przypadku immunitetu państwa i jego własności powstaniem norm uniwersalnych jest przedstawianie materii immunitetu jurysdykcyjnego państwa w polskich podręcznikach prawa międzynarodowego. W przypadku podręcznika Wyrozumskiej

Dole Food Co. v. Patrickson, 538 U.S. 468, 479 (2003). We added that '[f]oreign sovereign immunity' is not about 'chilling' or not chilling 'foreign states or their instrumentalities in the conduct of their business'. Ibid. (opinion of Kennedy, J.). Rather, the objective of the 'sovereign immunity' doctrine (in contrast to other conduct-related immunity doctrines) is simply to give foreign states and instrumentalities 'some protection', at the time of suit 'from the inconvenience of suit as a gesture of comity'. Ibid.; see also ante, at 17-18. Compare conduct-related immunity discussed in, e.g., Nixon v. Fitzgerald, 457 U.S. 731, 749 (1982) (absolute official immunity), Harlow v. Fitzgerald, 457 U.S. 800, 813 (1982) (qualified official immunity); Pinochet, supra, at 202 (conduct-related immunity for 'public acts'). Third, the State Department's and our courts' own historical practice reflects this classic view. For example, in 1952, the Department issued the Tate Letter adopting a restrictive view of sovereign immunity, essentially holding foreign sovereign immunity inapplicable in respect to a foreign state's commercial activity. Letter from Jack B. Tate, Acting Legal Adviser, U.S. Dept. of State, to Acting U.S. Attorney General Philip B. Perlman (May 19, 1952), reprinted in 26 Dept. State Bull. 984-985 (1952), and in Alfred Dunhill of London, Inc. v. Republic of Cuba, 425 U.S. 682, 711-715 (1976) (App. 2 to opinion of White, J.). As the dissent acknowledges: 'After the Tate Letter's issuance, the Executive evaluated suits involving pre-Tate Letter conduct under the Letter's new standard when determining whether to submit suggestions of immunity to the courts. The Court, likewise, seems to have understood the Tate Letter to require this sort of application. In National City Bank of N. Y. [v. Republic of China, 348 U.S. 356 (1955)], the Court suggested that the Letter governed in a case involving pre-1952 conduct, though careful consideration of the question was unnecessary there. [Id.], at 361'. Post, at 11-12 (emphasis and alterations added)", http://www.law.cornell.edu/supct/ $\mathrm{html} / 03-13 . \mathrm{ZC} 1 . \mathrm{html}$

Szeroka analiza patrz: G. Born, International civil litigation in United States courts: commentary \& materials, The Haque 1996, s. 199 i nast.

${ }^{51}$ Preambuła Konwencji Europejskiej o immunitecie Państwa sporządzona w Bazylei dnia 16 maja 1972, http://www.vilp.de/Plpdf/p014.pdf.

52 Konwencja europejska wyraźnie wytwarza normę subregionalną, „Pragnąc ustanowić w swoich wzajemnych stosunkach wspólne zasady w odniesieniu do zakresu immunitetu jurysdykcyjnego jednego Państwa do jurysdykcji sądów innego Państwa, z myślą zapewnienia zastosowania się do orzeczeń wydanych przeciwko innemu Państwu; Zważywszy, iż przyjęcie owych zasad przyczyni się do przyspieszenia prac nad harmonizacją w dziedzinie prawnej przez Państwa członkowskie Rady Europy”. 
i Czaplińskiego autorzy odnotowują kontrowersje i zajmują wobec nich stanowisko neutralne ${ }^{53}$. W podręczniku Bierzanka i Symonidesa immunitet jurysdykcyjny jest omawiany tylko w kontekście przywilejów i immunitetów dyplomatycznych; w podręczniku nie odnotowano nawet problemu immunitetu jurysdykcyjnego państwa i jego własności ${ }^{54}$. W podręczniku Góralczyka i Sawickiego problem immunitetu i kontrowersji w odniesieniu do materii jest odnotowany, jednak wywód dowodzi zarówno opowiadania się za koncepcją immunitetu absolutnego - co jest dobrym prawem uczonych, jak i, najdelikatniej rzecz ujmując, spóźnionego dostrzegania rzeczywistości, gdy autorzy stwierdzają - w kwietniu 2009 r., że KPM ,przygotowuje projekt artykułów w tym (tzn. immunitetu jurysdykcyjnego państwa - uwaga J. M.) zakresie" ${ }^{55}$.

$\mathrm{Z}$ tej fotografii polskiego wykładu immunitetu państwa i jego własności z przyczyn oczywistych wyłączam sposób prezentacji zagadnienia przez Shawa - w przetłumaczonym na język polski podręczniku - mieszczący się w standardzie „,zachodnim”; autor wyodrębnia w samodzielnym rozdziale materię immunitetu jurysdykcyjnego i kompleksowo ją analizuje ${ }^{56}$.

Taki polski stan referowania materii jest różny zarówno od standardu amerykańskiego, za jaki można uznać podręcznik Beurgenthala i Murphy’ego, w którym to przypadku immunitet jurysdykcyjny jest kompleksowo przedstawiony w obszernym rozdziale i stanowisko autorów-rządu USA (za immunitetem ograniczonym) jest wyraźnie przedstawione ${ }^{57}$. Odbiega również od standardu europejskiego - za reprezentatywny, dla którego można uznać umiędzynarodowiony podręcznik Cassese; autor wskazuje na zmianę w prawie i uznaje za istotne wyłączanie spod immunitetu aktów jure gestionis or jure privatorum - stanowiska autora dowodzi pośrednio sam tytuł podrozdziału: Immunities and other limitations on sovereignty ${ }^{58}$.

Te różnice są istotne, gdyż wobec braku formalnego i ogólnego stanowiska polskiego w odniesieniu do immunitetu jurysdykcyjnego państwa i jego własności to podręczniki z jednej strony w jakimś stopniu są refleksem polskiego punktu widzenia, z drugiej zaś strony to na nich kształcą się polscy funkcjonariusze publiczni - to oni będą decydować o stanowisku Polski w stosunku do immunitetu państwa i jego własności, i kolejnych kwestii immunitetu.

${ }^{53}$ W. Czapliński, A. Wyrozumska, Prawo międzynarodowe publiczne. Zagadnienia systemowe, Warszawa 1999, s. 199-201.

${ }^{54}$ R. Bierzanek, J. Symonides, Prawo międzynarodowe publiczne, Warszawa 2005, s. 177 i 178 oraz 180 i 181.

55 W. Góralczyk, S. Sawicki, Prawo międzynarodowe publiczne w zarysie, Warszawa 2009, s. 134 i 135.

${ }_{56}$ M. N. Shaw, Prawo międzynarodowe, Warszawa 2000, s. 375-413.

57 Th. Beurgenthal, S. D. Murphy, Public International Law in a Nutshell, St. Paul 2002, s. $222-256$.

${ }^{58}$ A. Cassese, International Law, Oxford 2001, s. 91-93. 


\section{d. Zakres analizy}

Jednak nie te niezwykle istotne problemy i wyzwania wyznaczają wyłączny obszar badania. Chcę zbadać również na ile z jednej strony jest faktem w przypadku immunitetu organizacji międzynarodowych i ich własności istnienie uniwersalnych norm zwyczajowego prawa międzynarodowego regulujących przedmiotową materię, mających za podstawę powtarzalne regulacje w umowach jednostkowych ${ }^{59}$, $\mathrm{z}$ drugiej strony, czy i w jakim stopniu możliwy będzie w stosunku do immunitetu organizacji międzynarodowych i ich własności powtórzenie modus operandii zastosowanego - z powodzeniem - w przypadku Konwencji wiedeńskiej prawa traktatów organizacji międzynarodowych i realizowanego w odniesieniu do projektu konwencji regulującej odpowiedzialność organizacji międzynarodowych tzn. wytworzenie spójnego zespołu konwencji NZ.

\section{e. Teza}

Tezą badania jest brak uniwersalnych norm zwyczajowego prawa międzynarodowego immunitetu jurysdykcyjnego państwa - fakt anihilacji istniejących (w przeszłości) przez zmiany stanów faktycznych w odniesieniu do immunitetu jurysdykcyjnego państwa i jego własności ${ }^{60} \mathrm{i}$ immanentna niemożność wypracowania regulacji uniwersalnej - w odniesieniu do każdej organizacji międzynarodowej wobec niejednorodności kategorii organizacja międzynarodow ${ }^{61}$ nawet $\mathrm{w}$ podgrupie międzyrządowych organizacji międzynarodowych - a uprawnionymi z tytułu immunitetu jurysdykcyjnego są również organizacje niemające takiego charakteru np. INTERPOL, ale przede wszystkim $\mathrm{MKCK}^{62}$. Mam bowiem podstawową wątpliwość, czy można w odniesieniu do organizacji międzynarodowych powtórzyć wprowadzającą konstatację preambuły Konwencji ,,[c]onsidering that the jurisdictional immunities of States and their property are generally accepted as a principle of customary international law" - iż organizacje międzynarodowe są i powinny być

${ }^{59}$ W przypadku państw potwierdził to Projekt Deklaracji Praw i Obowiązków Państw z 1949 r. W artykule 2 („Every State has the right to exercise jurisdiction over its territory and over all persons and things therein, subject to the immunities recognized by international law".), http://untreaty. un.org/ilc/texts/instruments /english/commentaries/2_1_1949.pdf.

${ }^{60}$ Nic na aktualności nie utraciła ocena Sonnenfeld: „Obecnie trudno jest mówić o panującej normie prawa zwyczajowego w tej (immunitetu - przyp. J. M.) dziedzinie”. R. Sonnenfeld, op. cit., s. 4.

${ }^{61}$ To zróżnicowanie jest silniejsze niż w przypadku państw, acz również w ich przypadku fundamentalna zasada prawa międzynarodowego „,...) równości” jest konfrontowana z praktyką pochodną istnieniu np. państw miniaturowych i mimo że można odłożyć moment, to nie będzie można nie udzielić odpowiedzi prawnej na to wyzwanie.

${ }^{62}$ Obawiam się zresztą, że to istniejące i pogłębiające się zróżnicowanie organizacji międzynarodowych wymusi wielość nie tylko przyszłych kodyfikacji, ale również rozszczepienie KPT II. 
uprawnione z tytułu immunitetu jurysdykcyjnego sądów państw i czy społeczność międzynarodowa byłaby skłonna taką normę zaakceptować, uznając za uprawnioną $\mathrm{z}$ jej tytułu każdą organizację mieszczącą się w jednorodnym formalnie podzbiorze międzyrządowych organizacji międzynarodowych poszerzonym o inne organizacje - beneficjentów tego statusu ad casum. Jak również, jaka w odniesieniu do organizacji międzynarodowych byłaby treść wyjątków od immunitetu i czy analogicznie generalne ich określenie jak i rezygnacja z ich generalnego określenia jest w przypadku przyszłej potencjalnej kodyfikacji możliwa?

\section{Immunitet jurysdykcyjny organizacji międzynarodowej - stan prawny - rekonstrukcja normy}

W sytuacji, w której brak jest normy/norm abstrakcyjnych i generalnych wyznaczających treść immunitetu jurysdykcyjnego organizacji międzynarodowych ${ }^{63}$ badanie możliwe jest wyłącznie ad casum, poprzez odwoływanie się do regulacji wytworzonych na potrzeby poszczególnych organizacji ${ }^{64} \mathrm{i}$, następnie, weryfikacja albo falsyfikacja hipotezy zakładającej istnienie modelu. Nie cofając się ponad konieczność w przeszłość, wskazać należy, że mocą §2 Konwencji dotyczącej przywilejów i immunitetów Narodów Zjednoczonych „Organizacja Narodów Zjednoczonych, jej majątek i aktywa, gdziekolwiek i w czyichkolwiek rękach by się znajdowały, korzystają z przywileju niepodlegania jakiejkolwiek procedurze sądowej, chyba że Organizacja w jakimś szczególnym wypadku zrzeknie się wyraźnie tego immunitetu" ${ }^{65}$. Podobnie, tylko że silniej, immunitet jurysdykcyjny organizacji wyspecjalizowanych stanowi artykuł III Konwencji o przywilejach i immunitetach organizacji wyspecjalizowanych „Organizacje wyspecjalizowane, oraz majątek i aktywa tych organizacji, bez względu na to, gdzie i w czyich rękach się znajdują, korzystają z pelnego (podkr. - J. M.) immunitetu jurysdykcyjnego (...)"66.

${ }^{63}$ Szerzej J. Menkes, A. Wasilkowski, Organizacje międzynarodowe. Prawo instytucjonalne, Warszawa 2010, s. 240-243.

${ }^{64}$ Immunitety i przywileje organizacji nadają i wyznaczają ich zakres umowy - bilateralne lub multilateralne albo akty jednostronne państw lub organizacji międzynarodowych.

${ }^{65}$ Teksty polskie konwencji (jeśli nie jest wskazane to wyraźnie) A. Przyborowska-Klimczak, W. Staszewski, Prawo dyplomatyczne. Wybór dokumentów, Lublin 2001.

${ }^{66}$ To, relatywne, wzmocnienie treści normy w stosunku do Konwencji odnoszącej się do Narodów Zjednoczonych w polskim tłumaczeniu nie ma uzasadnienia w wersji angielskiej (ani we francuskiej). „The specialized agencies, their property and assets, wherever located and by whomsoever held, shall enjoy immunity from every form of legal process except in so far as in any particular case they have expressly waived their immunity”, gdyż powtórzono normę „,2. The United Nations, its property and assets wherever located and by whomsoever held, shall enjoy immunity from every form of legal process except insofar as in any particular case it has expressly waived its immunity. It is, however, understood that no waiver of immunity shall extend to any measure of execution". 
Oczywiście w przypadku, gdy załamanie jednolitego, uniwersalnego reżimu prawnego prawa zwyczajowego absolutnego immunitetu jurysdykcyjnego państwa jest wynikiem, w decydującym stopniu, działań USA, niezbędne jest zbadanie stosunku USA do immunitetu jurysdykcyjnego organizacji międzynarodowych. Badanie zapoczątkowuje stwierdzenie, że Konwencja o przywilejach i immunitetach Narodów Zjednoczonych weszła w życie w stosunku do USA (dopiero) 29 kwietnia $1970 \mathrm{r}^{67}$ Abstrahując od kwestii: - nieistotnej w tym przypadku (a znacznie szerszej) kwestii stosunku USA do traktatów wielostronnych; - i zakresu immunitetu jurysdykcyjnego, z którego tytułu ONZ był do tego czasu uprawniony w USA, to najistotniejszym jest fakt, że USA uznały immunitet absolutny ONZ już po dacie, w której poprzez the Tate Letter odrzuciły prawo państwa do bycia uprawnionym z tytułu takiego (tzn. absolutnego) immunitetu. W stosunku do Konwencji o przywilejach i immunitetach organizacji wyspecjalizowanych USA, nie będąc również jej stroną, uznały potrzebę złożenia 8 lipca 1975 r. Deklaracji odnoszącej się do deklaracji rządu NRD pochodnej akcesji tego państwa do Konwencji; również Deklaracja nie wskazuje na podważanie zakresu absolutnego immunitetu jurysdykcyjnego organizacji wyspecjalizowanych ${ }^{68}$. Konwencję o bezpieczeństwie personelu Organizacji Narodów Zjednoczonych i personelu współdziałającego Stany Zjednoczone podpisały 19 grudnia 1994 r. i mimo że umowy nie ratyfikowały, to nie wniosły również zastrzeżeń do jej artykułu 6 ust. 1 przedmiotowo istotnego.

Jednak nawet akceptując amerykańską perspektywę, decydujący charakter ma regulacja zawarta $w$ United States International Organizations Immunities Act (IOIA) z 29 grudnia 1945 r., zgodnie z którą „,(b) International organizations,

${ }^{67}$ Patrz: http://www.state.gov/documents/organization/143863.pdf.

${ }^{68}$ Patrz: DECLARATION relating to the declaration made upon accession by the German Democratic Republic concerning application to Berlin (West) Received on: 8 July 1975 FRANCE UNITED KINGDOM OF GREAT BRITAIN AND NORTHERN IRELAND UNITED STATES OF AMERICA ,[The declaration by the German Democratic Republic refers] to the Quadripartite Agreement of 3 September 1971. 3 This Agreement was concluded in Berlin between the Governments of the French Republic, the Union of Soviet Socialist Republics, the United Kingdom of Great Britain and Northern Ireland and the United States of America. [The Government sending this communication is not a party to the Quadripartite Agreement and is] therefore not competent to make authoritative comments on its provisions". The Governments of France, the United Kingdom and the United States wish to bring the following to the attention of the States Parties to the [instrument referred to in the above-mentioned communication.] When authorising the extension of [this instrument] to the Western Sectors of Berlin, the authorities of the Three Powers, acting in the exercise of their supreme authority, ensured in accordance with established procedures that [this instrument is] applied in the Western Sectors of Berlin in such a way as not to affect matters of security and status. ,Accordingly, the application of [this instrument] to the Western Sectors of Berlin continues in full force and effect. „The Governments of France, the United Kingdom and the United States do not consider it necessary to respond to any further communications of a similar nature by States which are not signatories to the Quadripartite Agreement. This should not be taken to imply any change in the position of those Governments in this matter". Registered ex officio on 8 July 1975, http://treaties.un.org/doc/Publication/UNTS/Volume\%20973/volume-973-A-521-English.pdf. 
their property and their assets, wherever located, and by whomsoever held, shall enjoy the same immunity from suit and every form of judicial process as is enjoyed by foreign governments, except to the extent that such organizations may expressly waive their immunity for the purpose of any proceedings or by the terms of any contract". I nie podlega wątpliwości zarówno fakt, że w 1945 r. przyznanie organizacjom międzynarodowym immunitetu jurysdykcyjnego „takiego z jakiego korzystają państwa" oznaczało przyznanie w USA immunitetu absolutnego, jak i to, że Ustawa z 1976 r. Foreign Sovereign Immunities Act (FSIA) zmieniła-ograniczyła zakres immunitetu państw obcych przed sądami amerykańskimi, co jednak nie skutkuje automatyczną zmianą zakresu immunitetu jurysdykcyjnego wyznaczoną IOIA. Ustawodawca (amerykański) znał bowiem zakres immunitetu wyznaczony IOIA i mógł, uchwalając FSIA, ustawowo dostosować zakres immunitetu jurysdykcyjnego przyznany mocą IOIA organizacjom międzynarodowym do przyznanego państwu. Potencjalne wątpliwości są konsekwencją modus operandi ustawodawcy amerykańskiego wykorzystanego w 1945 r. Posłużenie się dla wyznaczenia treści immunitetu jurysdykcyjnego organizacji międzynarodowych konstrukcją blankietowego przepisu odsyłającego do znanego i ostrego przepisu, wyznaczającego treści immunitetu jurysdykcyjnego państwa miało w tamtym czasie szereg zalet:

- po pierwsze, przyspieszyło wytworzenie potrzebnej regulacji na terytorium USA (w stosunku do przyszłego i niepewnego zdarzenia, jakim była konwencja międzynarodowa);

- po drugie, odsyłając do znanego i precyzyjnego przepisu, ułatwiało stosowanie prawa i zapobiegało ewentualnym trudnościom lub kontrowersjom w praktyce orzeczniczej;

- po trzecie, ujawniało ratio legis ustawodawcy, jakim było zapewnienie jednolitego traktowania państw i organizacji międzynarodowych w zakresie immunitetu jurysdykcyjnego.

Ceną, którą przychodzi jednak zapłacić po 1976 r. za korzyści uzyskane w roku 1945, jest wątpliwość co do wpływu zakresu immunitetu jurysdykcyjnego państwa wyznaczonego FSIA na immunitet jurysdykcyjny organizacji międzynarodowej wyznaczony IOIA ${ }^{69}$. Ratio legis ustawy z 1945 r. przemawiałby za zawężeniem immunitetu - odejściem od immunitetu absolutnego, jednak w dobrej praktyce państw materię odesłania po utracie mocy obowiązującej przez przepis, do którego następuje odesłanie, reguluje się w przepisach wprowadzających, mając świadomość, że z jednej strony trudno, by przepis uchylony obowiązywał $\mathrm{w}$ odesłaniu, $\mathrm{z}$ drugiej jednak strony brak podstaw prawnych do automatycznego

${ }^{69}$ Potwierdzają to kontrowersje w orzecznictwie sądów amerykańskich, m.in. w sprawie Oss Nakalva v. Europejska Agencja Kosmiczna czy Atkinson v. Między-amerykański Bank Rozwoju; szerzej patrz: M. Hardcastle (autorka jest Legal Assistant w Berliner, Corcoran \& Rowe, LLP, Washington, D.C), Immunity of International Organizations, Wed., 12:20:24, 18 Aug. 2010, http:// embassylaw.com/2010/08/18\#0818-esa-iorg 
przeniesienia odesłania na nowy przepis - powyższy pożądany standard staranności, wymagany w relacjach krajowych, powinien być tylko podwyższony w relacjach międzynarodowych, gdy nie ma podstaw domagania się od podmiotu zewnętrznego bieżącego śledzenia zmian $\mathrm{w}$ prawie krajowym ${ }^{70}$. Dodatkowo nie można zlekceważyć faktu, że stanowiącej podstawę zawężenia immunitetu jurysdykcyjnego państwa doktryny ,act of State" 71 nie można przenosić mechanicznie na organizacje międzynarodowe, jeśli bowiem w przypadku państwa generalnie „działalność handlowa” (Section 1603 FSIA) ma charakter aktu iure gestionis, to nie jest tak, na pewno generalnie, w przypadku organizacji międzynarodowej ${ }^{72}$.

Przywołane regulacje tworzą wspólny standard międzynarodowy i można na ich podstawie uznać istnienie uniwersalnej normy prawa zwyczajowego, regulującej immunitet jurysdykcyjny organizacji międzynarodowych. Powszechność normy potwierdzają uregulowania w umowach kształtujących status prawny organizacji regionalnych; szczególnie w tym przypadku, gdy stronami tych umów partykularnych są państwa opowiadające się za odrzuceniem absolutnego immunitetu jurysdykcyjnego państwa. Z takimi stanami mamy do czynienia w przypadkach Rady Europy, Wspólnot Europejskich i NATO:

- Rada Europy. Podstawą prawną immunitetu jest artykuł 3 Porozumienia ogólnego w sprawie przywilejów i immunitetów Rady Europy z 2 września 1949 r. (,Rada, jej majątek i aktywa, bez względu na to, gdzie i w czyim posiadaniu się znajdują, korzystają z immunitetu jurysdykcyjnego, chyba że w konkretnym przypadku Komitet Ministrów wyraźnie zrzeknie się tego immunitetu”.);

- Wspólnoty Europejskie. Immunitet potwierdza (wynika to z Preambuły) Protokół o przywilejach i immunitetach Wspólnot Europejskich z 8 kwietnia $1965 \mathrm{r}$;

- NATO. Zgodnie z artykułem 5 Umowy dotyczącej statusu Organizacji Traktatu Północnoatlantyckiego, przedstawicieli narodowych i personelu międzynarodowego z 20 września 1951 r. „Organizacja, jej majątek i aktywa, gdziekolwiek się znajdują i przez kogokolwiek są zarządzane, będą korzystać z immunitetu od jakiegokolwiek postępowania prawnego, z wyjątkiem szczególnych przypadków, w których Przewodniczący Rady Zastępców, działając w imieniu Organizacji, może w sposób wyraźny zezwolić na zrzeczenie się tego immunitetu".

W odniesieniu do immunitetu jurysdykcyjnego organizacji i organów międzynarodowych (bo nie wyłącznie ,klasycznych” organizacji, ale szerzej ,instytucji międzynarodowych") stwierdzić można istnienie sieci pojedynczych umów,

${ }^{70}$ Jak zaś stan prawny jest pogmatwany, wskazuje Diplomatic and Consular Privileges and Immunities From Criminal Jurisdiction Summary of Law Enforcement Aspects, http://www. state.gov/documents/ organization/20047.pdf.

${ }_{71}$ Patrz: A. F. Lowenfeld, International litigation and arbitration, St. Paul 2002, s. 501 i nast.

${ }^{72}$ Ilustruje to np. przypadek Międzynarodowej Rady Cyny (ITC) organizacji powołanej w celu stabilizowania cen cyny na rynku światowym poprzez jej zakupy przy obniżce cen i sprzedaż zapasów w korzystniejszych warunkach; szerzej J. Menkes, A. Wasilkowski, op. cit., s. 227. 
których zgodne postanowienia tworzą w przedmiotowym zakresie standard - stan uniwersalnego prawa zwyczajowego. Wniosek taki ma potwierdzenie również w zgodnym stanowisku doktryny, reprezentatywny jest podręcznik Kirgis ${ }^{73}$.

\section{Wyzwanie czasu}

Jest składnikiem najnowszej historii Polski wręczenie w roku 1999 przez działaczy politycznych Akcji Wyborczej Solidarność Marka Jurka ${ }^{74}$, Michała Kamińskiego ${ }^{75}$ i Tomasza Wołka ${ }^{76}$ pamiątkowego ryngrafu z Matką Boską Augusto Pinochetowi będące demonstracją przeciwko międzynarodowej walce ofiar chilijskiej dyktatury lat 1973-1989 o postawienie przed sądem generała Pinocheta. Jednocześnie posłowie na Sejm RP podnosili zastrzeżenia w trakcie debaty nad ratyfikacją Europejskiej Konwencji o ochronie praw człowieka i podstawowych wolności w stosunku do możliwości kierowania spraw przeciwko państwu do zewnętrznego organu sądowego.

Polska uznawała immunitet jurysdykcyjny, czemu dał wyraz SN w sprawie Józefa Ivaldi przeciwko Wanda Montwid-Biatłozorowa, stwierdzając, że „(...) powszechna jest zasada prawa narodów, że przedstawiciele dyplomatyczni państw obcych w materii cywilnej są zupełnie zwolnieni od jurysdykcji sądów krajowych, a immunitet ten dawniejszy i rozleglejszy nawet od immunitetu monarchów i suwerenów państw obcych, jest uznaną powszechnie koniecznością w stosunkach pomiędzy narodami, powoduje go bowiem idea niezawisłości państw, niedająca się pogodzić z wykonywaniem jurysdykcji krajowej wobec przedstawiciela innego państwa, a obok tego potrzeba zapewnienia posłom zupełnej niezależności przy wykonywaniu powierzonych im czynności, niezależność, zaś ta nie byłaby zabezpieczona dostatecznie, gdyby poseł miał podlegać sądom państwa, przy którym jest uwierzytelniony (...), to też immunitet sądowy przedstawicieli dyplomatycznych, uświęcony powszechnym zwyczajem i prawem narodów, znalazł w wielu państwach swój wyraz również w ustawodawstwie" "77. Również po II wojnie światowej Polska konsekwentnie reprezentowała stanowisko o absolutnym charakterze immunitetu jurysdykcyjnego i była $\mathrm{w}$ tym stanowisku „bezstronna”. Równie silnie sprzeciwiała się jurysdykcji w stosunku do państwa, broniąc nieuczciwego dyplomaty w sprawie T. Siennicki przeciwko

${ }^{73}$ F. L. Kirgis, Jr., International Organizations in Their Legal Setting, St. Paul 1993, s. 19-53.

74 Poseł X kadencji Sejmu PRL oraz I, IV i V Sejmu RP, w latach 2005-2007 Marszałek Sejmu.

75 Poseł III i IV kadencji Sejmu RP i deputowany VI i VII Parlamentu Europejskiego.

76 Dziennikarz m.in. redaktor naczelny dzienników „Życia Warszawy” i „Życia”.

77 Zbiór Orzeczeń Sądu Najwyższego. Orzeczenia Izby Pierwszej (Cywilnej), rok 1925 (drugie półrocze), poz. 123. 
SHEA Construction $\mathrm{Ltd}^{78}$, jak i Instytutu kultury austriackiej w Warszawie zwalniającego pracownika $\mathrm{z}$ naruszeniem obowiązującego prawa pracy (sąd uznał absolutny immunitet jurysdykcyjny obcego państwa, nie badając nawet, czy Instytut jest, na mocy prawa austriackiego, objęty statusem podmiotowym ${ }^{79}$ ). Stan ten ulega jednak zmianie, ilustruje to uzasadnienie Postanowienia SN w sprawie P.E.H. S.A. w K. v. Recep Tayyip E., M.Hilmi G., Abdullatif S., Ali B. v. Skarbowi Państwa Republiki Tureckiej; SN stwierdził, że „Podstawy immunitetu jurysdykcyjnego upatruje się w samej istocie suwerenności i równości wszystkich państw, stwierdzając, że zasady te nie pozwalają na podległość państwa prawu i jurysdykcji innego państwa. Nie można jednak pomijać, że powszechnie przyjęta zasada ograniczonego immunitetu jurysdykcyjnego państwa obcego sprawia, iż nie obejmuje on działań państwa w zwykłym obrocie cywilnym i gospodarczym, co świadczy o tym, że w istocie nie sama zasada równości i suwerenności państw jest źródłem immunitetu państwa obcego, lecz pewne zasady wypracowane i modyfikowane przez przepisy i zwyczaje międzynarodowe. (...) Immunitet państwa w takich sprawach przyjmuje się powszechnie i stosuje w praktyce, a europejska konwencja o immunitecie państwa jest potwierdzeniem istnienia tego zwyczaju międzynarodowego. (...) $\mathrm{Z}$ tych względów trzeba stwierdzić nie ma jurysdykcji krajowej w rozpoznawanej sprawie, a więc w sprawie, w której obce państwo i jego najwyższe organy zostały pozwane o odszkodowanie za szkodę wyrządzoną zarzucanym czynem niedozwolonym, związanym z działalnością władczą państwa, objętą immunitetem jurysdykcyjnym państwa obcego"80.

\section{Wnioski}

Immunitet jurysdykcyjny podmiotu prawa międzynarodowego nie jest wbrew łatwym i spektakularnym wypowiedziom ani fas ani ne fas. Jest moralnie neutralny, jest dobry, bo obowiązuje. Nie można poddawać immunitetu jurysdykcyjnego w stosunkach międzynarodowych ocenie z punktu widzenia aksjologii moralnej, zarazem konieczne jest wmontowanie go/zapewnienie jego więzi z l'ordre public. Państwo jest zwolnione z obowiązków na podstawie immunitetu jurysdykcyjnego tylko przed sądem obcego państwa - nie może korzystać/ powoływać się na immunitet przed sądem „własnym”. Pozwala to stwierdzić, że immunitet jurysdykcyjny chroni przed actio wyłącznie na fori zewnętrznym, legitymowany do actio może z nim wystąpić - tyle, że - na fori państwa (w tym sensie można uznać immunitet jurysdykcyjny za normę proceduralną).

\footnotetext{
${ }^{78}$ Szerzej R. Sonnenfeld, op. cit.

79 Wyrok z 25 marca 1987 r., sygn. akt I PRN 55/87.

${ }^{80}$ Postanowienie z dnia 13 marca 2008 r. III CSK 293/07.
} 
Stan prawny i faktyczny ulega zmianie w odniesieniu do organizacji międzynarodowych ${ }^{81}$, które nie posiadają sądów (w takim rozumieniu); w odniesieniu do nich brak fori ${ }^{82}$ skutkuje brakiem actio $^{83}$.

\section{Prognoza - scenariusze}

W przedmiotowo i metodologicznie wyznaczonym zakresie badania prawniczego nie mieści się prognoza zmian stanu normatywnego ${ }^{84}$. Jednak od tej, co do zasady pożądanej, ortodoksji dopuszczalne są odstępstwa uzasadnione szczególnym stanem faktycznym ściśle powiązanym z prawnym. I z taką szczególną sytuacją uzasadniającą, a wręcz nakazującą odstępstwo od dyrektywy ogólnej mamy do czynienia $\mathrm{w}$ przypadku immunitetu jurysdykcyjnego organizacji międzynarodowych. Decyduje o tym wskazany wcześniej brak uniwersalnych norm immunitetu (państwa) w ścisłym powiązaniu z podmiotową specyfiką organizacji międzynarodowych.

W prognozie rozważyć należy trzy, najbardziej prawdopodobne, scenariusze:

1. Zachowanie stanu istniejącego ${ }^{85}$. Na jego rzecz w perspektywie średnio terminowej-10-15 lat, a tylko taką jest racjonalna, przemawiają:-konserwatyzm podmiotów tworzących prawo - powolność jego zmian; - trudności z wytworzeniem regulacji ujmującej we wspólnych ramach tak zróżnicowane podmioty, jakimi są organizacje międzynarodowe (ze względu na różnice pomiędzy IGOs i NGOs jak i wewnątrz IGOs pomiędzy organizacjami aktorami a organizacjami forum);

${ }^{81}$ Zdaniem Martin Nerisky rzecznika prasowego Sekretarza Generalnego ONZ Ban Ki-moon wypowiadającego się o przypadku Ruud Lubbers „As a general principle, I think you are aware of the general immunity that exists, (...) I am not talking about specific cases or specific areas, but as a general rule" (cyt. za P. Goodenough, op. cit.).

82 Zarzut ten został podniesiony przez Cynthię Brzak (przypadek „Ruud Lubbers”) w liście do Prezydenta Obamy „Since the United Nations internal justice system is not independent or credible, the use of diplomatic immunity to prevent U.N. staff access to national legal systems is morally repugnant and inconsistent with human rights norms, (...) Moreover, many in the legal field also believe it to be unconstitutional" (cyt. za P. Goodenough, op. cit.).

${ }^{83} \mathrm{~W}$ przedmiotowej sprawie opinię tę podzielił, Nasr Ishak przewodniczący Rady Funkcjonariuszy UNHCR i stanowisko to miało silną podstawę w raporcie wewnętrznej instytucji kontrolnej ONZ Office of Internal Oversight Service (OIOS), na którą wywarto naciski w celu powstrzymania ogłoszenia raportu (Francis Montil b. z-ca szefa śledczych OIOS przytoczył wypowiedź wysokiego funkcjonariusza biura b. Sekretarza Generalnego ONZ Kofi A. Annana „(...) that the complainant was an American woman, and therefore a neurotic attention-seeker who was no doubt exaggerating the incident".).

${ }^{84}$ Pozytywizm ogranicza wręcz badanie prawa do deskryptywnej analizy prawa istniejącego.

${ }^{85}$ Zdaniem Jenks zakres immunitetu jurysdykcyjnego jest współzależny od sytuacji międzynarodowej; W. Jenks, International Immunities, London 1961. 
- racjonalność stanu istniejącego - korzyści w praktyce w połączeniu z możliwością uzyskania w przypadku organizacji międzynarodowych stanu respektowania prawa, któremu to celowi służy ograniczenie immunitetu państwa bez odchodzenia od immunitetu absolutnego organizacji międzynarodowych. Jeśli dwie pierwsze przesłanki wnioskowania nie wymagają w tym miejscu uzasadnienia; tzn. konserwatyzm-powolność w tworzeniu prawa międzynarodowego jest faktem konkludentnym, a trudności były przedmiotem wcześniejszej analizy, to rozwinąć należy, uznaną za przesłankę wnioskowania o zachowaniu stanu istniejącego, racjonalność absolutnego immunitetu jurysdykcyjnego organizacji międzynarodowych. Państwa/społeczność międzynarodowa potrzebują organizacji międzynarodowych - narzędzia wytworzone przez nie do realizacji celów, których nie można w ogóle lub przy znacząco wyższych kosztach zrealizować bez nich. Narzędzie to wytworzone i oparte na współpracy jest relatywnie znacząco wrażliwe na zaburzenia we współpracy, a takimi jest zarówno zmiana stanu prawnego niemająca pełnego poparcia w społeczności międzynarodowej, jak i zderzenie organicznego multilateralizmu organizacji międzynarodowej z unilateralizmem państwa wykonującego jurysdykcję sądowniczą w stosunku do innego podmiotu prawa międzynarodowego. Zarazem jeśliby zaakceptować argument, że u źródeł konieczności odejścia od absolutnego immunitetu jurysdykcyjnego państwa i jego własności, stała niezgoda na nadużywanie prawa - na przyzwolenie na praktyki chronienia się przez państwa pod parasolem prawa (immunitetu absolutnego) w odniesieniu do czynów prawo naruszających i brak innych niż sąd narzędzi reagowania na naruszenia prawa i zapobiegania naruszeniom w przyszłości ${ }^{86}$, bo bez wątpienia inaczej państwo nie może wpływać na zachowanie innego państwa - bronić swojego (i swoich obywateli) uprawnionego interesu. To w przypadku organizacji międzynarodowych jest inaczej; państwo, zarówno członek organizacji (IGOs), jak i dopuszczające ją (zarówno IGOs, jaki i NGOs), do działania na własnym terytorium dysponuje wystarczającym instrumentarium prawnym, by uniemożliwić je/zapobiec naruszaniu

86 Ta przyczyna nie podlega zaś wątpliwości, na co wskazywała m.in. KPM (patrz: Raport, s. 160 i 161) ,The crucial question in any study of State immunities is the extent to which States are to be accorded jurisdictional immunities. The doctrine of State immunities was formulated in the nineteenth century during which States confined their activities to functions traditionally recognized as properly within the spheres of State duties and responsibilities. Immunities were accorded to States on the grounds of their sovereign equality and political independence, irrespective of the nature of their activities. However, this doctrine, which has been styled 'absolute' or 'unqualified' immunity, has not been followed with consistency in the practice of States. 27 A glance at the more recent practice of States and contemporary legal opinions will clearly show that immunity has not been accorded in all cases, and that several limitations have been recognized, with the result that in several categories of cases immunity has been denied. Theories have been advanced advocating limitation of the domain of State immunities. These theories, which have sometimes been styled 'restrictive', appear to be gaining further ground in State practice", http://untreaty.un.org/ilc/ publications/yearbooks/Ybkvolumes(e)/ILC_1978_v2_p2_e.pdf. 
prawa $^{87}$ lub spowodować realizację odpowiedzialności. Działania i zaniechania organizacji międzynarodowych (IGOs) są podejmowane w wykonaniu uchwał ich organów, nad którymi państwa członkowskie wykonują nadzór lub w których wspólnie wykonują część suwerenności, w przypadku zaś państwa, w obrębie którego jurysdykcji terytorialnej operuje organizacja, to każdy taki przypadek wymaga uprzedniego przyzwolenia dla wyrażenia, którego konstytutywnym czynnikiem jest rachunek korzyści-kosztów.

2. Zachowanie/zmiana częściowa zakresu przedmiotowego immunitetu jurysdykcyjnego organizacji międzynarodowych - fragmentacja immunitetu organizacji międzynarodowych o charakterze regionalnym ${ }^{88}$. Ten scenariusz wydawać by się mógł szczególnie prawdopodobny ${ }^{89}$. Na rzecz takiej oceny przemawia fakt w postaci wyodrębnienia się europejskiej przestrzeni prawnej $\mathrm{UE}^{90}$, wyznaczonej ramami normatywnymi prawa europejskiego, ściśle powiązanej z systemem prawnym Rady Europy obejmującej prawo europejskie praw człowieka ${ }^{91}$, ale i ograniczony immunitet jurysdykcyjny państwa i jego własności - Konwencję bazylejskąa2 . Wątpliwości budzi jednak nie tylko nader ograniczony zasięg Konwencji bazylejskiej, ale i potencjalne różne drogi ewolucji otwierane przez (aktualną) praktykę ${ }^{93}$.

a. Orzecznictwo w przedmiotowym zakresie bynajmniej nie uprawnia do wypowiadania sądów jednoznacznych:

- sprawy Waite and Kennedy v. Germany ${ }^{94}$ i Beer and Regan v. Germany ${ }^{95}$. Wszyscy wnioskodawcy, zatrudnieni przez zagraniczne firmy, będący w dyspo-

${ }^{87}$ Ta ocena odnosi się do korzystania z immunitetu organizacji międzynarodowych, nie zaś immunitetu funkcjonariuszy; tak jak jest oczywistym brak tożsamości immunitetu jurysdykcyjnego państwa $\mathrm{z}$ immunitetem dyplomatycznym.

${ }^{88}$ Podkreśla to Koskenniemi „14. The relationship between special regimes and general international law. A special regime may derogate from general law under the same conditions as lex specialis generally"; patrz: M. Koskenniemi, Fragmentation of International Law: Difficulties Arising from the Diversification and Expansion of International Law. Report of the Study Group of the International Law Commission. Addendum, Appendix. Draft conclusions of the work of the Study Group, http://untreaty.un.org/ilc/documentation/english/a_cn4_1682_add1.pdf.

${ }^{89}$ Tak np. W. Werner, The never-ending closure: constitutionalism and international law, [w:] N. Tsagourias, N. K. Tsagourias (eds.), Transnational Constitutionalism. International and European Perspectives. Cambridge 2007, s. 339, patrz również: K. Kuhnert, Bosphorus - Double standards in European human rights protection?, „Utrecht Law Review, Research Paper” 2006, vol. 2, s. 177 i nast. (szczególnie 168-169).

${ }^{90}$ Por. E. Gaillard, I. Pingel-Lenuzza, op. cit., s. 6-8.

91 Patrz: również odniesienia do materii praw człowieka na s. 85 i nast.

92 Patrz również: M. Koskenniemi, op. cit., szczególnie s. 85 i 86, 102-113, 118, http://daccess -dds-ny.un.org/doc/UNDOC/LTD/G06/610/77/PDF/G0661077.pdf.

${ }_{93}$ A nie podlega wątpliwości, że praktyka ta może iść w kierunku uniwersalizacji standardu europejskiego na co może wskazywać orzeczenie Cour d'Appel, Paris, 19 June 1998, w sprawie UNESCO - United Nations Educational, Scientific and Cultural Organisation, in the person of its legal representatives v. Max-Henri Boulois, Yearbook of Commercial Arbitration 1999, vol. 24a, s. 294-295.

${ }^{94}$ Wyrok z 18-02-1999 ETPC publikacja 1999-I. Dotyczy naruszenia art 6-1.

${ }_{95}$ A. Reinisch, Waite and Kennedy v. Germany, Application No. 26083/94; Beer and Regan v. Germany, Application No. 28934/95, AJIL 1999, vol. 93, no. 4, 933-938. 
zycji Europejskiej Agencji Kosmicznej w celu świadczenia usług w europejskiej przestrzeni Centrum Operacyjne w Darmstadt. Kiedy ich umowy nie zostały przedłużone wszczęli postępowanie przed sądem pracy w stosunku do ESA, podnosząc, że byli - zgodnie z prawem niemieckim - pracownikami ESA. Sądy uznały skargi za niedopuszczalną wobec powołania się ESA na immunitet jurysdykcyjny ${ }^{96}$, stwierdzając, że immunitet jurysdykcyjny stanowi przeszkodę dla postępowania sądowego; Trybunał Konstytucyjny odmówił przyjęcia odwołania. Skarżący podnieśli, przed ETPC, naruszenia artykułu 6(1) EKPC. Trybunał uznał, że argumenty sądów niemieckich na rzecz immunitetu jurysdykcyjnego nie mogą przemawiać na rzecz arbitralności decyzji. Jednak Zdaniem ETPC zastosowane zasady immunitetu jurysdykcyjnego miały słuszny cel, ,przyznanie przywilejów i immunitetów organizacji międzynarodowych było podstawowym środkiem zapewnienia prawidłowego funkcjonowania takich organizacji, wolnym od jednostronnych ingerencji przez poszczególne rządy.

Trybunał uznał zarazem, że immunitety nie mogą wpływać na ochronę praw podstawowych; tak więc dla uznania immunitetu ESA decydujące i wystarczające było ustalenie, czy skarżący mieli skuteczną ochronę praw podstawowych i w konsekwencji w stwierdzeniu tego sądy niemieckie nie przekraczały swobodnego uznania - nie miało miejsca naruszenie praw podstawowych.

Uogólniając, w odniesieniu do stanowiska ETPC można wskazać analogię ze sprawą Solange I i II, bowiem Trybunał stwierdził de facto, że tak długo, jak organizacje międzynarodowe uprawnione $\mathrm{z}$ tytułu immunitetu jurysdykcyjnego respektują prawa podstawowe, są one chronione immunitetem jurysdykcyjnym ${ }^{97}$;

- sprawa Mothers of Srebrenica and the Netherlands/United Nations. Sąd w Hadze uznał immunitet jurysdykcyjny ONZ przed sądem holenderskim mimo, że strona skarżąca podniosła zarzut ludobójstwa. Sąd (wyrokując po orzeczeniu MTS w sprawie Al Adsani, and Behrami w której MTS stwierdził, że „states cannot (...) be held liable for the actions of national troops they made available for international peace-keeping missions. (...) Then the principal question in this incident comes up for discussion: whether the UN enjoys immunity or not. (...) At issue in this case is not a possible state immunity, but the immunity of an international organization, laid down in a treaty in so many words. Between these types of immunity, which are very dissimilar to each other, there is no hierarchical relationship; the one type does not extend "further", in general terms, and is not more "important" than the other. Decisive for the establishment of meaning of standards of immunity of international institutions is what the parties to the treaty agreed to in the founding treaty in question, (...) With regard to the UN it is true that it is indisputably the most important international institution in the international

\footnotetext{
${ }_{96}$ Art XV (2) Konwencji ESA i jej załącznika I.

${ }^{97} \mathrm{~W}$ sytuacji organizacji europejskich i transatlantyckich jest to jednak oczywiste zaś - ewentualne - dopuszczenie jurysdykcji w innych przypadkach jest możliwe, ale nie jest pewne.
} 
community, with an almost universal membership among states. (...) The UN acts objected to fall within the functional scope of this organization. It is particularly for acts within this framework that immunity from legal process is intended. (...) As far as the Court knows the UN to date has always invoked its immunity with regard to actions within the functional framework referred to just now, and no exceptions were ever made in practice. (...) On the basis of this the Court concludes that in international-law practice the absolute immunity of the $\mathrm{UN}$ is the norm and is respected. (...) A testing on the merits or comprehensive testing is also contrary to the ratio of the immunity of the $\mathrm{UN}$ as enshrined in international law. (...) Neither does the available, but scant, jurisprudence about the scope of the standard of article 105, subsection 1 of the UN Charter afford grounds for the conclusion that a national court, if and insofar as it has scope for testing, can proceed in any other way than with the utmost reticence. (...) Now that the interpretation of article 105 of the UN Charter does not offer grounds for restricting the immunity, the question arises whether other international-law standards - outside of the UN frame of reference - prompt a different opinion. This inquiry into conflicting standards is necessary because there are insufficient grounds for accepting a full and unconditional prevailing of international-law obligations of the State under the UN Charter over other international-law obligations of the State. The rule of article 103 of the UN Charter invoked by the State does not always and right away bring relief in the event of conflicting obligations of a peremptory nature (ius cogens) or conflicting human rights obligations of an international customary law nature. (...) The Contracting parties are obliged to punish all acts defined by this Convention (Genocide Convention - przyp. J. M.) as genocide within the boundaries set in article VI of the Convention. (...) That the issue in this case was the relationship between state immunity and the prohibition on torture and not the relation between the immunity of international organizations and the prohibition on genocide does not lead to a different opinion in the present case. Just as little as there is any basis in law for a hierarchy between different types of immunity, there are no grounds for a hierarchy between different standards of ius cogens. (...) The Court concludes that this same ratio implies that article 6 ECHR cannot be a ground for exception to the - as said before, absolute - immunity under international law of the UN itself. (...) The judgment The Court in the incident to have the Court declare it has no jurisdiction 6.1. declares that it has no jurisdiction to hear the action against the United Nations."

3. Zmiana istniejącego prawa - wytworzenie norm ograniczających immunitet jurysdykcyjny organizacji międzynarodowych i ich własności do zakresu przedmiotowego, wyznaczonego ograniczonym immunitetem jurysdykcyjnym państwa i jego własności. Na rzecz tej zmiany - przeciwko zachowaniu status quo (niezależnie od chwili, w której to nastąpi) przemawia generalne nieakceptowanie, zarówno w społeczności wewnątrzpaństwowej, jak i międzynarodowej, zróżnicowania-dyskryminacji niemającej uzasadnienia w wartościach. Ograniczony 
immunitet jurysdykcyjny państwa i absolutny immunitet jurysdykcyjny organizacji międzynarodowych oznacza dyskryminację podmiotowo wyznaczonej grupy spośród podmiotów prawa międzynarodowego. Ta dyskryminacja (pozytywna/ negatywna) niemająca uzasadnienia opartego na aksjologii moralnej jest jednoznacznie sprzeczna z zasadą prawa międzynarodowego - równością wobec prawa. Wydaje się, że argumenty pragmatyczne na rzecz zróżnicowania mogą, a być może nawet powinny ulec osłabieniu w konfrontacji z normą równości - obowiązującą, bo dobrą. Oczywiście jestem daleki od uznania obecnej dyskryminacji w prawie za ,ustawowe bezprawie" (w terminologii Radbrucha ${ }^{98}$ ), jednak racje mające za podstawę wartości, nawet jeżeli nie decydują o obowiązywaniu prawa, to w sposób istotny wpływają na decyzje o legislacji i jej kierunek.

${ }_{98}$ Szerzej J. Oniszczuk, Filozofia i teoria prawa, Warszawa 2008, s. 323-330. 